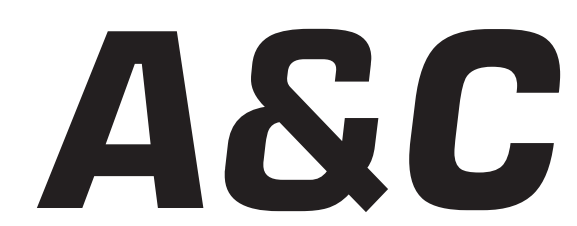

Revista de Direito Administrativo \& Constitucional

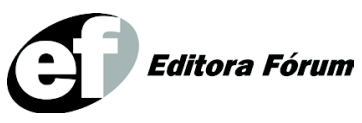

A\&C R. de Dir. Administrativo e Constitucional, Belo Horizonte, ano 6, n. 24, p. 1-246, abr.jun. 2006 


\section{A\&C REVISTA DE DIREITO ADMINISTRATIVO E CONSTITUCIONAL}

\section{IPDA}

Instituto Paranaense

de Direito Administrativo

Direção Geral

Romeu Felipe Bacellar Filho

Direção Editorial

Paulo Roberto Ferreira Motta

Direção Executiva

Emerson Gabardo

Conselho de Redação

Edgar Chiuratto Guimarães

Adriana da Costa Ricardo Schier

Célio Heitor Guimarães

Conselho Editorial

Adilson Abreu Dallari

Alice Gonzáles Borges

Carlos Ari Sundfeld

Carlos Ayres Britto

Carlos Delpiazzo

Cármen Lúcia Antunes Rocha

Celso Antônio Bandeira de Mello

Clèmerson Merlin Clève

Clóvis Beznos

Enrique Silva Cimma

Eros Roberto Grau

Fabrício Motta

Guilhermo Andrés Muñoz (in memoriam)

Jaime Rodríguez-Arana Muñoz

Jorge Luís Salomoni
José Carlos Abraão

José Eduardo Martins Cardoso

José Luís Said

José Mario Serrate Paz

Juan Pablo Cajarville Peruffo

Juarez Freitas

Julio Rodolfo Comadira

Luís Enrique Chase Plate

Lúcia Valle Figueiredo

Manoel de Oliveira Franco Sobrinho

(in memoriam)

Marçal Justen Filho

Marcelo Figueiredo

Márcio Cammarosano

Maria Cristina Cesar de Oliveira
Nelson Figueiredo

Odilon Borges Junior

Pascual Caiella

Paulo Eduardo Garrido Modesto

Paulo Henrique Blasi

Paulo Neves de Carvalho (in memoriam)

Paulo Ricardo Schier

Pedro Paulo de Almeida Dutra

Regina Maria Macedo Nery Ferrari

Rogério Gesta Leal

Rolando Pantoja Bauzá

Sérgio Ferraz

Valmir Pontes Filho

Yara Stropa

Weida Zancaner

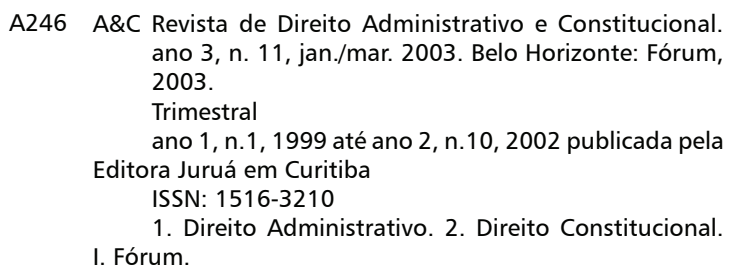

A246 A\&C Revista de Direito Administrativo e Constitucional. ano 3, n. 11, jan./mar. 2003. Belo Horizonte: Fórum, 2003.

Trimestral

ano 1, n.1, 1999 até ano 2, n.10, 2002 publicada pela Editora Juruá em Curitiba

ISSN: 1516-3210

1. Direito Administrativo. 2. Direito Constitucional. I. Fórum.

CDD: 342 CDU: 33.342

(c) Editora Fórum Ltda. 2006

Todos os direitos reservados. É proibida a reprodução total ou parcial, de qualquer forma ou por qualquer meio eletrônico ou mecânico, inclusive através de processos xerográficos, de fotocópias ou de gravação, sem permissão por escrito do possuidor dos direitos de cópias (Lei nº 9.610, de 19.02.1998).

\section{Editora Fórum Ltda}

Av. Afonso Pena, 2770 - 15\%16ªndar - Funcionários

CEP 30130-007 - Belo Horizonte/MG - Brasil

Tel.: 08007043737

Internet: www.editoraforum.com.br

e-mail: editoraforum@editoraforum.com.br
Editor responsável: Luís Cláudio Rodrigues Ferreira Projeto gráfico e diagramação: Luis Alberto Pimenta Revisora: Olga M. A. Sousa

Pesquisa jurídica: Fátima Ribeiro - OAB/MG 74868

Bibliotecária: Alessandra Rodrigues da Silva CRB 2778/MG 6a Região

Os conceitos e opiniões expressas nos trabalhos assinados são de responsabilidade exclusiva de seus autores.

Impressa no Brasil / Printed in Brazil

Distribuída em todo Território Nacional 


\title{
Ilegalidade de presumirem-se depósitos bancários como enriquecimento ilícito do agente público para fins de improbidade administrativa
}

\author{
Mauro Roberto Gomes de Mattos \\ Advogado no Rio de Janeiro-RJ-Brasil. Vice Presidente do Instituto Ibero-Americano de Direito \\ Público (Capítulo Brasileiro) - IADP. Membro da Sociedade Latino-Americana de Direito do Tra- \\ balho e Seguridade Social. Membro do IFA - International Fiscal Association. Conselheiro efetivo \\ da Sociedade Latino-Americana de Direito do Trabalho e Seguridade Social. Co-Coordenador da \\ Revista Ibero-Americana de Direito Público - RIADP (Órgão de Divulgação Oficial do IADP)
}

\begin{abstract}
Sumário: 1 Atos de improbidade administrativa que importam em enriquecimento ilícito - 2 Cabe à administração pública provar o nexo de causalidade entre $\mathrm{o}$ ato de improbidade administrativa que importa enriquecimento ilícito em razão da função pública exercida - 3 Enriquecimento sem causa - ilegalidade de presumir-se o enriquecimento ilícito do agente público - 4 Ilegalidade de presumir-se depósito bancário como renda para fins de enriquecimento ilícito - 5 Quebra de sigilos bancário e fiscal do agente público não pode se dar sem motivo justificado e fundamentado - 6 Conclusão

Palavras-chave: Improbidade administrativa. Enriquecimento ilícito. Enriquecimento sem causa Agente público. Princípio da presunção de inocência. Princípio da prova. Processo administrativo disciplinar. Depósito bancário. Ônus da prova. Nexo de causalidade. Estado Democrático de Direito. Sigilo fiscal. Sigilo bancário.
\end{abstract}

\section{Atos de improbidade administrativa que importam em enriquecimento ilícito}

$\mathrm{O}$ art. $9^{\circ}$, caput, é o primeiro, dentre três artigos (10 e 11), que tipifica os atos de improbidade administrativa a que alude a Lei $\mathrm{n}^{\circ}$ 8.429/92.

Ele versa sobre os atos de improbidade administrativa que importem enriquecimento ilícito por parte do agente público, em razão do exercício da respectiva função pública.

Desta forma, para a tipificação do que vem descrito na conduta prevista no art. $9^{\circ}$ da Lei de Improbidade Administrativa, deverão estar presentes os seguintes requisitos:

- dolo do agente público ou do terceiro; ${ }^{1}$

- vantagem patrimonial oriunda de um comportamento ilegal do agente público ou do terceiro;

- nexo de causalidade entre a ilicitude da vantagem obtida e o

"Inexistindo prova de que o funcionário público agiu de má-fé, presume-se a sua boa-fé, o qual deve ser excluído do pólo passivo da demanda (...)"(TJ/SP, RT n 735/266). 
exercício funcional do agente público ou do terceiro.

Havendo a lesão ao bem jurídico (requisitos acima) estará configurado o presente artigo, sendo que no primeiro requisito descrito deverá estar devidamente caracterizada a vontade livre e consciente do agente público (dolo) em enriquecer ilicitamente, mediante uma atuação funcional abusiva. Não há previsão a título de culpa neste tipo de ilícito. ${ }^{2}$

No tocante ao segundo requisito, qual seja, a vantagem patrimonial auferida pelo agente público, a mesma deverá ser decorrente de um proveito pecuniário ilegal, proveniente do desempenho do seu cargo/função pública.

Pergunta-se: Esta vantagem ilegal do agente público deverá trazer prejuízo para o ente público?

$\mathrm{O}$ art. $9^{\circ}$ é claro em fixar o enriquecimento ilícito do agente público quando ele aufere vantagem patrimonial ilegal, em função de seu cargo ou emprego, o que significa dizer que a Administração Pública precisa ser lesada para a ocorrência da presente subsunção. Isto porque somente se enriquece injustamente aquele que causa empobrecimento para outrem.

O recebimento de vantagem indevida, em razão da função ou do cargo público, traz, em seu âmago, uma ilicitude manifesta, resultante de um ato comissivo ou omissivo do agente público. O prejuízo pode ser financeiro como também moral, visto que o agente público como representante do poder público não pode enriquecer sem que traga para a Administração determinada perda.

O enriquecimento injusto possui como suporte um desequilíbrio patrimonial ou moral do ente público, inerente ao desempenho funcional do agente público. Alteramos nosso posicionamento anterior, justamente por termos feito uma reflexão mais adequada sobre o tema, separandonos da linha de pensamento dos ilustres Marino Pazzaglini Filho e de Francisco Otávio de Almeida Prado, ${ }^{3}$ por entender-mos que não se presume, ainda mais quando se trata de enriquecimento, visto que deverá ser provado o devido empobrecimento do poder público, sob pena de não configurar os elementos do presente tipo.

Tanto é assim que o valor a ser atribuído para a ação de improbidade administrativa deve corresponder ao do dano ou ao enriquecimento ilícito

\footnotetext{
2 "Logo, não há que se falar em enriquecimento ilícito involuntário culposo. Não é curial, nem lógico, v.g., o recebimento de comissão, gratificação ou percentagem, por imprudência ou negligência, para facilitar negócio superfaturado ou para a alienação de bens públicos, por preço inferior ao mercado" (PAZZAGLINI FILHO, Marino. Lei de Improbidade Administrativa Comentada. São Paulo: Atlas, 2002. p. 56).

3 PRADO, Francisco Otávio de Almeida. Improbidade Administrativa. São Paulo: Malheiros, 2001. p. 72.
}

A \& C R. de Dir. Administrativo e Constitucional, Belo Horizonte, ano 6, n. 24, p. 97-140, abr.jun. 2006 
comprovado em procedimento administrativo disciplinar.

Não resta dúvida que o enriquecimento ilícito do agente público estabelecido no caput do art. $9^{\circ}$, da presente Lei é aquele que onera ao erário, através de um ato ilícito, ou como dito pelo Ministro Luiz Fux:" "A lesividade que impõe o ressarcimento é aquela que onera, sem benefícios, o erário público.”

Sem a devida prova do ato ilícito que causou prejuízo ao erário não há nexo de causalidade para configuração do enriquecimento ilícito do agente público.

A lesividade ao erário decorre da prática de uma ilegalidade, não podendo ser presumida ou intuída, sob pena de estimular-se e consolidarse o enriquecimento sem causa do Poder Público.

Não demonstrado o dano, descabe a pretensão de ressarcimento ao erário, visto que não há como se falar em enriquecimento ilícito por parte do agente público quando ausente a diminuição do patrimônio público. ${ }^{5}$

Não foi de modo aleatório que a Lei de Improbidade Administrativa (art. 12, parágrafo único) estabeleceu a necessidade do Juiz, ao fixar

\footnotetext{
${ }^{4}$ STJ. Rel. Min. Luiz Fux, Resp. n 407075/MG, $1^{\text {a }}$ T., DJ de 23 set. 2002. p. 244

5 A propósito, seguem os seguintes arestos do Tribunal de Justiça de Minas Gerais: "Administrativo. Ação Civil Pública por Ato de Improbidade Administrativa. Lesividade. Ausência. Improcedência do Pedido. Inteligência do art. 12, da Lei 8.429/1992. É improcedente o pedido constante da vestibular de Ação Civil Pública, quando não provado dano efetivo ao Erário municipal como conseqüência de atos praticados em desacordo com a forma prescrita" (TJ/MG. Rel. Des. Dorival Guimarães Pereira, Processo n 1.0000.05.417542-7/000, $5^{a}$ CC, DJ de 20 set. 2005). "Ação Civil Pública - Condenação em pecúnia - Dano Efetivo - Prova - Inexistência - Improcedência. "O pedido de condenação em pecúnia pressupõe a existência de dano efetivo a algum interesse difuso ou coletivo. Vale dizer, parte-se do pressuposto de que o réu agiu de forma a destruir ou trazer prejuízo de alguma forma aos bens protegidos. (...) Disso resulta que se do ato nenhum dano adveio não haverá porque pleitear a indenização. Esta pressupõe prejuízo causado por outrem." Não se vislumbrando nenhuma prova de lesividade ao erário público relativamente às alegadas irregularidades (despesas sem quitações, sem os devidos procedimentos licitatórios e créditos suplementares), inclusive a caracterização de má-fé, ou, ainda, conduta culposa e enriquecimento indevido dos ex-administradores, improcede o pedido de condenação em pecúnia dos ex-administradores. "Mesmo na hipótese de prática de ato em desacordo com os princípios norteadores da Administração Pública (art. 37 da Constituição Federal), é necessária a caracterização de dano ou de proveito patrimonial, conforme se infere do que dispõe a Lei n $8249 / 92$, como condição para prosseguimento do feito e a aplicação de penalidades em sede de ação civil pública" (aspas no original) (TJ/MG. Rel. Des. Gouvêa Rios, Processo n 1.0392.04.911932-5/001(1), $1^{\text {a }}$ CC, DJ de 16 set. 2005). "Para que a ação civil pública por improbidade administrativa seja procedente é preciso que fiquem bem delineados o dano ao patrimônio público e a demonstração da atitude do agente administrativo qualificada pela desonestidade e a intenção de obter para si ou para outrem, vantagem indevida. Logo, improcede a ação se, embora desobedecendo à formalidade legal, não houver comprovado prejuízo ao erário" (TJ/MG. Rel. Des. Schalcher Ventura, Processo n 1.0392.04.911651-1/001(1), 3ª CC, DJ de 6 set. 2005). "Ação Civil Pública. Inexistência de Prova Hábil de Lesão ao Patrimônio Público. Conseqüente inocorrência de Ato de Improbidade Administrativa. Indemonstrada a ocorrência de lesão ao patrimônio público por ação ou omissão, dolosa ou culposa, do agente, impõe-se a improcedência do pedido, em ação civil pública fundada em ato de improbidade administrativa" (TJ/MG. Ap. Cível no 1.0000.00.2506459/000, Rel. Des. Hyparco Immesi; DJMG 29 ago. 2003). "Ação Civil Pública. Ressarcimento de Danos ao Erário. Dano. Prova. A condenação ao ressarcimento de danos ao erário exige a prova do efetivo prejuízo" (TJ/MG. Ap. Cível no 1.0000.00.188895-7/000, Rel. Des. Garcia Leão, DJMG 24 nov. 2000).
} 
as respectivas penas, levar em conta a extensão do dano causado, assim como o proveito patrimonial obtido pelo agente público ou pelo terceiro beneficiado.

A esse respeito, ensina Maria Sylvia Zanella Di Pietro ${ }^{6}$ que: “(...) A aplicação da lei de improbidade exige bom-senso, pesquisa da intenção do agente, sob pena de sobrecarregar-se inutilmente o judiciário com questões irrelevantes, que podem ser adequadamente resolvidos na própria esfera administrativa. A própria severidade das sanções previstas na Constituição está a demonstrar que o objetivo foi o de punir infrações que tenham um mínimo de gravidade, por apresentarem conseqüências danosas para o patrimônio público (em sentido amplo), ou propiciarem benefícios indevidos para o agente ou para terceiros. A aplicação das medidas previstas na lei exige observância do princípio da razoabilidade, sob o seu aspecto de proporcionalidade entre meios e fins."

Destaquem-se, ainda, as lições de Hely Lopes Meirelles: ${ }^{7}$ "O só fato de o ato ser lesivo não acarreta ao Prefeito a obrigação de indenizar. Necessário se torna, ainda, que, além de lesivo e contraditório ao direito, resulta de conduta abusiva do prefeito no desempenho do cargo ou a pretexto de seu exercício.' E '... se o ato não se macula de má-fé, de corrupção, de culpa de maior monta, não deve acarretar a responsabilidade pessoal da autoridade.' (STF, RDA 48/171; TJRS, RT 143/198, 145/165 e 149/607)." [aspas no original].

Por derradeiro, o terceiro e último requisito para que ocorra a subsunção no caput do art. $9^{\circ}$ trata-se do nexo de causalidade entre a ilicitude da vantagem obtida e o exercício funcional do agente público, sendo o mesmo de curial importância, pois sem ele fica descaracterizado o ato de improbidade administrativa.

Isto porque o exercício funcional irregular, com mácula a probidade administrativa e a moral, é que desencadeia os atos de improbidade administrativa que importam enriquecimento ilícito. Se o ato inquinado de ímprobo não for em razão da função pública exercida pelo agente, faltará o devido e necessário nexo de causalidade.

Entendemos que esse último requisito é de suma importância, pois se o enriquecimento ilícito não for caracterizado em razão do desempenho do munus público exercido, ficará descaracterizado o delito previsto na Lei de Improbidade Administrativa. Essa prova do nexo de causalidade deverá

${ }^{6}$ DI PIETRO, Maria Sylvia Zanella. Direito Administrativo. São Paulo: Atlas, 2003. p. 435.

${ }^{7}$ MEIRELLES, Helly Lopes. Direito Municipal Brasileiro. 6. ed. São Paulo: Malheiros, 1993. p. 583-84.

A \& C R. de Dir. Administrativo e Constitucional, Belo Horizonte, ano 6, n. 24, p. 97-140, abr.jun. 2006 
ser feita pela Administração Pública.

2 Cabe à administração pública provar o nexo de causalidade entre o ato de improbidade administrativa que importa enriquecimento ilícito em razão da função pública exercida

O princípio da presunção de inocência vem contido no art. $5^{\circ}$, LVII, da CF. Estabelece esse princípio uma garantia de que ninguém será considerado culpado até o trânsito em julgado de sentença penal condenatória. $^{8}$

No processo administrativo disciplinar incide o mesmo princípio, que possui uma presunção juris tantum, podendo ser elidida ou afastada mediante "a existência de um mínimo necessário de provas produzidas por meio de um devido processo legal e com a garantia da ampla defesa". ${ }^{9}$

Em boa hora, a era da verdade sabida foi descartada do cenário do processo administrativo para dar lugar à verdade real, em que os fatos e as provas devem desconstituir a presunção de inocência do servidor público.

Não se julga mais administrativamente pelo fator político, em que a vontade da Administração Pública era a prevalente, independentemente de a materialidade ou as provas do procedimento serem contrárias ao entendimento do Poder Público.

Isto porque a "presunção de inocência condiciona toda condenação a uma atividade probatória produzida pela acusação e veda taxativamente a condenação, inexistindo as necessárias provas". ${ }^{10}$

Por esse princípio, necessariamente deverá o acusador provar que o servidor/agente praticou um ato delituoso, pois é vedada a condenação que contraria a prova dos autos: " 1 - O ônus da prova dos fatos constituídos da pretensão penal pertence com exclusividade à acusação, sem que se possa exigir a produção por parte da defesa de provas referentes a fatos negativos (provas diabólicas)." ${ }^{11}$

O Estado Democrático de Direito, do qual o Brasil é signatário, tem

\footnotetext{
"Prefeito Municipal. Desvio de renda pública. Afronta ao art. 1 , I, do Decreto-Lei n 201/67. Crime em tese. Denúncia. Ausência de causas que a rejeitem. Inteligência do art. 43 do CPP. Afastamento do cargo e prisão preventiva. Insuficiência de prova. Presunção de inocência. A denúncia deve ser recebida, pois o fato narrado, de desvio de renda pública, configura crime, em tese, e não há causa explícita para sua rejeição. Ademais, a peça acusatória está formalmente perfeita. Não havendo qualquer objeção para o exercício da ação penal, nos termos dos arts. 41 e 43 do CPP, o afastamento do cargo e a decretação da prisão preventiva do Prefeito não se aplicam nessa fase, pois não há prova cabal para decretação dessas medidas, que se apresentam como excepcionais e extremadas, pena de afronta à presunção constitucional de inocência. Precedentes da Corte. Denúncia recebida" (TJ/PR. Rel. Des. Jorge Wagih Massad, Processo n 129586900, $1^{\text {a }}$ Câmara Criminal, julgado em 5 jun. 2003).

9 MORAES, Alexandre de. Constituição do Brasil Interpretada. São Paulo: Atlas, 2002. p. 385

${ }^{10}$ MORAES, Alexandre de. Constituição do Brasil Interpretada. São Paulo: Atlas, 2002. p. 385.
} 
na presunção de inocência um de seus princípios, sendo que em decorrência do mesmo qualquer cidadão, inclusive o agente público, não poderá figurar no rol dos culpados pelo cometimento de ato ilícito se não for provado, pelo órgão ou ente apurante, que cometeu qualquer ilícito ou falta disciplinar. As chamadas provas diabólicas, que são plantadas de maneira irregular, obtidas por meios ilícitos, não são admitidas, pois o acusado no processo disciplinar não tem que provar que é inocente de qualquer acusação a ele imputada. Quem tem o dever e a obrigação de provar a responsabilidade disciplinar do agente público é a Administração Pública. Exemplo: no caso de haver uma acusação de crime de estelionato, onde é imputada ao agente público a prática da figura típica contida no art. 171, do Código Penal, quem deverá provar que houve ou não o crime?

Ora, a resposta é óbvia, sendo que a prova do fato típico cabe à Administração Pública tendo em vista que o agente público, por militar em seu favor a presunção de inocência, não terá que provar que é inocente; a Comissão Disciplinar de Inquérito é que terá que obter provas contundentes que houve ou não um lesado e que foi na condição de servidor público que foi cometido o ato ilícito, tendo em vista que nenhuma acusação pessoal presume-se provada.

No presente caso a hipótese é a mesma, pois compete ao ente de direito público demonstrar o nexo de causalidade do ato de improbidade administrativa que importe enriquecimento ilícito com a função ou o cargo desempenhado pelo agente.

O princípio da prova é inverso, tendo em vista que compete à acusação provar que o servidor público é culpado, militando em favor do acusado o princípio da presunção de inocência.

Esta presunção de inocência só poderá ser elidida com a devida prova (constatação) de que houve falta disciplinar, pois in dubio pro reo.

Aliás, sobre a presunção de inocência e o princípio do in dubio pro reo, o $\mathrm{STF}^{12}$ assim sentenciou: "Nenhuma acusação pessoal presume-se provada. Não compete ao réu demonstrar a sua inocência. Cabe ao MP comprovar, de forma inequívoca, a culpabilidade do acusado. Já não mais prevalece, em nosso sistema de direito positivo, a regra que, em dado momento histórico do processo político brasileiro (Estado Novo), criou para o réu, com a falta de pudor que caracteriza os regimes autoritários, a obrigação de o acusado provar a sua própria inocência. (Decreto-Lei $\mathrm{n}^{\circ}$

${ }_{11}$ MORAES, Alexandre de. Constituição do Brasil Interpretada. São Paulo: Atlas, 2002. p. 385.

12 STF. Rel. Min. Celso de Mello, HC n 73.338/RJ, $1^{\text {a }}$ T., RTJ 161/264.

A \& C R. de Dir. Administrativo e Constitucional, Belo Horizonte, ano 6, n. 24, p. 97-140, abr.jun. 2006 
88, de 20.12.37, art. 20, $\mathrm{n}^{\mathrm{O}} 5$.)"

Assim, deverá a Comissão Disciplinar, irrecusavelmente, verificar a ocorrência dos seguintes elementos de prova a serem produzidas contra o acusado:

- que ela seja licitamente obtida;

- que se pratique e se desenvolva com observância do devido processo legal;

- e que ela seja suficiente para elucidar os fatos apurados.

Se for provado o enriquecimento ilícito do agente público sem que haja uma correlação com a função exercida, haverá a carência da ação de improbidade, por falta do aludido nexo de causalidade a que se refere o caput do art. $9^{\circ}$, da Lei ${ }^{\circ}$ 8.429/92.

A suficiência da prova é a questão mais intrigante na apuração disciplinar, porque mesmo sendo analisada em caráter subjetivo pela Comissão Disciplinar, ela deverá ser robusta, sob pena de se invalidarem apenamentos embasados sob a fragilidade. Tendo em vista que "a previsão do in dubio pro reo é um dos instrumentos processuais previstos para garantia de um princípio maior, que é o princípio da inocência" ${ }^{13}$ ele só poderá ser ilidido com robusta e suficiente prova em contrário.

A jurisprudência da Corte Constitucional da Espanha, ${ }^{14}$ sobre a presunção de inocência, se encaixa perfeitamente nos princípios declinados, pois também se coaduna com os elementos embasadores do Estado Democrático de Direito: "La presución de inocencia rige sin excepciones en el ordenamiento administrativo sancionador garantizado el derecho a no sufrir sanción que no tenga fundamento en una previa actividad probatoria sobre la cual órgano competente pueda fundamentar un juicio razonable de culpabilidad. La apreciación que el órgano administrativo realice solo es suscetibile de revisão ante la jurisdicción ordinaria, sin que la valoración que ésta haga de la prueba pueda ser sustituida por la que mantenga la parte que discrepe de ella, no por la de este tribunal cuya función de defensa de la presunción de inocencia en la via de amparo se limita a comprobar si esta prueba existe, debiendo en tal caso considerar satisfechas las exigencias de la presunción, la cual sólo se vulnera no ha habido prueba o cuando la apreciación judicial de la misma es arbitraria o carente de conexión lógica con el contendio de las pruebas sobre las que se realiza."

\footnotetext{
13 MORAES, Alexandre de. Constituição do Brasil Interpretada. São Paulo: Atlas, 2002. p. 388.

${ }^{14}$ LOBO, José Maria Queiroz. Princípios de Derecho Sancionador. Granada: Comares, 1996. p. 92-93.
} 
Em assim sendo, deverá a Administração Pública provar que os acusados cometeram as transgressões que a eles são imputadas, sob pena de faltar justa causa para o ingresso da ação de improbidade.

Esta prova deverá ser inequívoca, suficiente para o apenamento proposto. Não basta a Comissão Processante refutar as alegações do servidor, com a inversão de posições, tendo em vista que compete ao Poder Público provar a ocorrência de fatos que desencadeiam a inobservância das normas disciplinares. ${ }^{15}$

O ônus da prova, como dito alhures, é da Administração, por intermédio da Comissão Processante, como se extrai também da lição de Ivan Barbosa Rigolin: ${ }^{16}$ "No processo administrativo disciplinar originário, o ônus de provar que o indiciado é culpado de alguma irregularidade que a Administração lhe imputa pertence evidentemente a esta. Sendo a Administração a autora do processo, a ela cabe o ônus da prova, na medida em que ao autor de qualquer ação ou procedimento punitivo sempre cabe provar o alegado."

Da mesma forma, Hely Lopes Meirelles, ${ }^{17}$ ao pronunciar-se sobre a instrução, concluiu que nos "processos punitivos as providências instrutórias competem à autoridade ou comissão processante e nos demais cabem aos próprios interessados na decisão de seu objeto, mediante apresentação direta das provas ou solicitação de sua produção na forma regulamentar".

Portanto, não basta que a Comissão Processante presuma a responsabilidade do servidor, deixando a ele a tarefa de provar sua inocência. No processo administrativo disciplinar, o ônus da prova incumbe à Administração, autora do procedimento. Inverter-se essa posição se afigura como ilegal e inadmissível em um estado de direito como o nosso, onde o acusado não precisa demonstrar sua inocência, pois compete ao acusador provar, cabalmente, o envolvimento do servidor na prática do crime.

Esta é a jurisprudência administrativa dominante: ${ }^{18}$ “(...) II - No Processo Administrativo Disciplinar o ônus da prova incumbe à Admi-

\footnotetext{
15 "Administrativo. Ação civil pública de reparação de danos ao erário público e de punição por improbidade administrativa e política. Só a comprovação induvidosa da prática de atos de improbidade administrativa/ política é capaz de embasar punição, não bastando indícios, mesmo veementes, se não confirmados por provas concretas e induvidosas, indicando a prudência judiciária ser preferível 'absolverem-se dez culpados e condenar-se um inocente'" (TJ/MG. Rel. Des. Orlando Carvalho, Ap. Cível no 1.0000.00346076-3/00. 1 a CC, DJ de 12 set. 2003).

${ }^{16}$ RIGOLIN, Ivan Barbosa. Comentários ao Regime Jurídico Único dos Servidores Públicos Civis. Rio de Janeiro: Saraiva, 1992. p. 283.

${ }^{17}$ MEIRELLES, Hely Lopes. Direito Administrativo. 20. ed. São Paulo: Malheiros, 1995. p. 591.
}

A \& C R. de Dir. Administrativo e Constitucional, Belo Horizonte, ano 6, n. 24, p. 97-140, abr.jun. 2006 
nistração. III - Para a configuração da inassiduidade habitual imputada ao servidor era imprescindível a prova da ausência de justa causa para as faltas ao serviço. A Comissão Processante não produziu a prova, limitandose a refutar as alegações do servidor. Inverteram-se as posições, tendo a Comissão presumido a ausência de justa causa, deixando ao servidor a incumbência de provar sua ocorrência. IV - Não provada a ausência de justa causa, não seria de aplicar-se a penalidade extrema ao servidor. V - O pedido de revisão deve ser provido para invalidar a demissão do servidor, com a sua conseqüente reiteração, na forma do art. 28 da Lei $n^{\circ} 8.112$, de 1990." (AGU, Processo n ${ }^{\circ}$ 10168.001291/95-93, Parecer AGU/MF-04/98, Parecer GQ 147 de 23 de abril de 1998, aprovado pelo Presidente da República em 27 abr. 1998.) "A penalidade do servidor deve adstringir-se às faltas sobre as quais existam, nos autos, elementos de convicção capazes de imprimir a certeza quanto à materialidade da infração. No processo disciplinar, o ônus da prova incumbe à Administração."

A inexistência de provas retira a possibilidade de qualquer punição ao servidor público, visto serem necessárias para a apenação a liquidez e a certeza. Não se admite a condenação ou a imposição de penalidades no caso de se intuir que determinado servidor público transgrediu as normas disciplinares. Sem prova concreta e robusta que não dê margem a dúvidas, não há como se punir o acusado em processo disciplinar.

Esta é a conclusão do Parecer CJ n ${ }^{\circ}$ 1/98 da AGU: “(...) Inexistência de provas concretas, precisas e definidas, comprovando irregularidades atribuídas aos indiciados. Ausente a materialidade do fato. Meros indícios sobrestecidos pela conduta tendenciosa da Comissão Processante não servem para qualificá-los de veementes. Inexistência de vícios processuais que maculem o apuratório. Absolvição de todos os servidores é a medida mais adequada, consubstanciada na máxima in dubio pro reo."

Sem materialidade ${ }^{19} \mathrm{e}$ autoria devidamente comprovadas, ${ }^{20}$ através de robustas provas, fica comprometida qualquer apenação ao servidor público, que tem em seu favor a presunção de inocência.

Portanto, sem que sejam demonstradas e provadas a materialidade e a autoria, a Comissão Processante fica desautorizada a imputar fatos delituosos ao servidor público.

\footnotetext{
${ }^{18}$ AGU. Processo no 03000-005894/95-10, Parecer GQ no 136, de 19 de janeiro de 1998, aprovado pelo Presidente da República em 26 jan. 1998.
}

A \& C R. de Dir. Administrativo e Constitucional, Belo Horizonte, ano 6, n. 24, p. 97-140, abr.jun. 2006 
No direito disciplinar, só a certeza possui o condão de submeter o servidor público a condenação. Sem esse requisito, in dubio pro reo.

Por essa razão é que o art. 168, da Lei $\mathrm{n}^{\circ}$ 8.112/90 condiciona o julgamento às provas dos autos: "Art. 168. O julgamento acatará o relatório da comissão, salvo quando contrário às provas dos autos."

Em assim sendo, a Comissão Processante não poderá ser julgadora autoritária, "espécie de dona da verdade", pois ela deverá ser fiel à materialidade e autoria, presentes nas provas dos autos.

Coube à Advocacia Geral da União, pelo Parecer GQ 149, advertir que o poder-dever do julgador não é absoluto, direcionando-se para o autoritarismo, devendo ser motivada a decisão correspondente ao que foi provado no respectivo procedimento disciplinar, sob pena de nulidade: "A destacada e a superior posição do julgador colocam-no numa situação acima dos interesses porventura existentes na tramitação processual inquisitiva. Daí que o uso do poder-dever que lhe é atribuído legalmente não é arbitrário, tampouco discriminatório. Não age quando lhe aprouver, nem como preferir. Age sim quando observar que a Comissão Processante atuou de maneira dissonante em relação às provas dos autos. Com sua discordância resguardam-se, simultaneamente, o interesse da Administração, tomada na sua generalidade, e o da Secretaria de Estado, a qual dirige, como auxiliar que é do Excelentíssimo Senhor Presidente da República. Então nos parâmetros do sistema da livre apreciação das provas, pode a autoridade julgadora desvincular-se das conclusões das comissões processantes e até julgar em sentido contrário, desde que o faça de maneira expositiva, fundamentada, levando sempre em consideração os elementos de prova do processo que autorizaram a repelir a opinião dada no relatório conclusivo.

Na formação de sua livre convicção, deve, ainda, a autoridade julgadora fulcrar-se não em elementos vagos, às vezes imprecisos, porém nos pontos lacunosos, conflitantes ou relegados a segundo plano pela Comissão Processante. Numa síntese, pode-se afirmar que as atividades do julgador deverão se pautar pelo princípio da legalidade, sem se deixar levar por

\footnotetext{
${ }^{19}$ A apenação é imprescindível desde que demonstradas, de maneira convincente, a materialidade e a autoria da infração, hipótese em que a edição do ato disciplinar torna-se compulsória. A caracterização da inobservância da proibição de receber a própria comissão, presente ou vantagem de qualquer espécie, compreendida no art. 117, XII, da Lei n 8.112, de 1990, pressupõe o exercício regular das atribuições cometidas ao servidor" (Parecer GQ 139 - AGU, de 30 jan. 1998, aprovado em 19 fev. 1998).

20 "Na hipótese em que a veracidade das transgressões disciplinares evidencia a conformidade da conclusão da Comissão de Inquérito com as provas dos autos, torna-se compulsório acolher a proposta de aplicação" (Parecer AGU nº GQ 135, 8 dez. 1997, aprovado em 18 dez. 1997).
} 
influências exógenas, estranhas aos autos do processo, baseando-se em parecer fundamentado, dimanado do órgão que lhe presta assessoramento jurídico."

Na dúvida, ${ }^{21}$ a Comissão Disciplinar Processante não poderá apenar o servidor público, pois a impessoalidade impede a fluência do sentimento pessoal do administrador, que tem nas provas a devida evidência capaz de elucidar os fatos apurados.

Assim, deverá a Comissão Processante provar, através de elementos contundentes e irrefutáveis, que o servidor transgrediu normas e condutas indispensáveis ao seu munus. Não compete ao acusado provar que é inocente e que não cometeu falta funcional. Essa inversão de valores é ilegal e dissociada do princípio da legalidade.

O princípio é o mesmo no processo judicial, tendo em vista que a ação de improbidade administrativa toma por base as provas colhidas na esfera interna dos órgãos apurantes. Cabe à Comissão Disciplinar apurar os fatos, e, após a conclusão do procedimento disciplinar, se entender haver materialidade e prova suficiente da autoria, remeter as peças probatórias ao MP para o ingresso da competente ação de improbidade administrativa.

E como a prova é o coração do processo, sem ela o procedimento torna-se ineficaz, ainda mais no caso da improbidade, em que as sanções são muito severas. Para a aplicação das penas, necessário se faz que haja a materialidade e certeza da autoria pois meras presunções, suspeitas e indícios não são suficientes para condenar o agente público. Somente a certeza, corroborada pelas provas dos autos, é que possui elementos para a configuração do ilícito praticado pelo acusado. Sem a certeza de delito, cessam as dúvidas, pois in dubio pro servidor público. ${ }^{22}$

\section{Enriquecimento sem causa - ilegalidade de presumir-se o enriquecimento ilícito do agente público}

O inc. VII, do art. $9^{\circ}$, da Lei $n^{\circ} 8.6429 / 92$, abrange o enriquecimento sem causa do agente público, durante o período em que ele exerce função, sem que haja uma causa lícita conhecida.

O princípio de que é defeso o enriquecimento sem causa nasceu do direito privado, não decorrendo de dispositivos contidos em texto

\footnotetext{
21 "A Administração pode editar o ato punitivo apenas na hipótese em que esteja convencida quanto à responsabilidade administrativa do servidor, a quem imputa a autoria da infração. A dúvida deve resultar em benefício do indiciado" (AGU - Processo no 0800.00328/97-56, Parecer GQ-173, de 19 nov. 1998).

22 Corroborando o que foi dito, segue o seguinte aresto do TRF-2a Região: "Criminal. Peculato. Provas. I. Ausência de provas de conhecimento de contrato de trabalho supostamente inexistente e de meios para isso a acusada aferir, o que nem o INSS conseguiu. II. Ausência de prejuízo ao INSS, eis que a única

A \& C R. de Dir. Administrativo e Constitucional, Belo Horizonte, ano 6, n. 24, p. 97-140, abr.jun. 2006
} 
legal. Esta teoria foi revelada inicialmente pelas jurisprudências francesa e italiana, que condenaram, de forma permanente, o locupletamento, ao afirmar freqüentemente o direito, que cabe ao empobrecido, à restituição do aumento da riqueza verificado à sua causa, a favor do outro patrimônio.

Em monografia específica, o mestre lusitano Martinho de Almeida, ${ }^{23}$ assim define o princípio em tela: "O enriquecimento sem causa é um evento, um fato que se verifica quando o patrimônio de alguém é aumentado, sem causa, pelo correlativo empobrecimento do patrimônio de outrem, embora não deixe de ser um conceito jurídico, um fato jurídico sintético com complexos formados à causa de fatos materiais concretos."

O enriquecimento sem causa, ou ilícito, apesar de não ter no início, sua origem na lei, sempre foi matéria puramente doutrinária, tendo como fundamentação três outros princípios: da moral, dos princípios gerais de direito e da eqüidade.

A verificação do enriquecimento sem causa se assenta na presença de quatro requisitos: a) o locupletamento de sujeito; b) o empobrecimento de outrem; c) o nexo de causalidade entre este empobrecimento e aquele locupletamento e d) a falta de uma causa jurídica para tais eventos.

Após a firme influência da doutrina, da jurisprudência e do direito comparado, o novo Código Civil contemplou o enriquecimento sem causa, tal como fez no princípio da boa-fé.

Dispõe a nova redação do art. 884, do Código Civil, em vigor a partir de janeiro de 2003: "Art. 884. Aquele que, sem justa causa, se enriquecer à custa de outrem, será obrigado a restituir o indevidamente auferido, feita a atualização dos valores monetários. Parágrafo único. Se o enriquecimento tiver por objeto coisa determinada, quem a recebeu é obrigado a restituí-la, e, se a coisa não mais subsistir, a restituição se fará pelo valor do bem na época em que foi exigido."

A seguir, o artigo 885 do referido Código Civil estipula: "Art. 885. A restituição é devida, não só quando não tenha havido causa que justifique o enriquecimento, mas também se esta deixou de existir."

prestação recebida foi devolvida integralmente. III. Aposentadoria novamente concedida à interessada, pouco tempo depois. IV. Absolvição de outras rés por falta de provas, igualmente funcionárias do INSS e participantes do ato concessório da aposentadoria, que deve estender-se à apelada. V. Recurso provido, por maioria, para absolver a apelante, por falta de provas" (TRF-2a Região. Rel. Des. Fed. Ivan Athié, Ap. Criminal $n^{\circ} 2.451,2000.02 .01 .035824-5,5^{\mathrm{a}} \mathrm{T}$., DJ de 13 jun. 2002).

${ }^{23}$ ALMEIDA, LP. Moitinho de. Enriquecimento sem Causa. Coimbra: Almedina, 1996. p. 25.

A \& C R. de Dir. Administrativo e Constitucional, Belo Horizonte, ano 6, n. 24, p. 97-140, abr.jun. 2006 
Foi pela redação do art. 886 que a Lei Substantiva Civil elencou que "não caberá a restituição por enriquecimento, se a lei conferir ao lesado outros meios para se ressarcir do prejuízo sofrido."

O enriquecimento injusto possui como ponto de partida um desequilíbrio patrimonial, que seria definitivo e real se não fosse coibido pelo direito e, sobretudo, pela obrigação restituidora daquele que o criou ou foi beneficiado ilegitimamente pelo empobrecimento alheio.

In casu, a lei de improbidade elencou o enriquecimento sem causa presumido como acréscimo patrimonial ou renda a descoberto, sem uma origem ou justificativa lícita de tal elevação. ${ }^{24}$

Não resta dúvida que para o agente público ser enquadrado no presente dispositivo deverá estar configurada a incompatibilidade ilícita da evolução do seu patrimônio.

A doutrina é dividida, entendendo a primeira corrente, à qual me filio, que a Administração Pública deverá provar que a elevação desproporcional do patrimônio do agente público derivou do exercício irregular ou abusivo da função exercida.

Aliás, é de se ressaltar, por oportuno, que a inversão do ônus da prova só ocorre em nosso direito positivo em situações especialíssimas de relevante interesse público ou de proteção a hipossuficientes, como verbi gratia: Código de Defesa do Consumidor (Lei no $8.078 / 90$ ), em prol do consumidor de produtos ou serviços lesados e Lei de Proteção ao Meio Ambiente (Lei $\mathrm{n}^{\mathrm{O}} 6.938 / 81$ ) onde o agressor é que tem de provar a falta de nexo causal entre a sua atividade e o desastre ambiental ocorrido.

Em abono ao que foi dito, agrega-se o fato do presente inciso VII atrelar-se ao caput do art. $9^{\circ}$ da Lei $\mathrm{n}^{\circ}$ 8.429/92, que é uníssono em estipular o tipo da improbidade administrativa como aquele que importa em enriquecimento ilícito, "em razão do exercício de cargo, mandato, função, emprego..." do agente público.

Neste sentido, não há como se presumir vantagem patrimonial indevida em razão do vínculo público, pois o princípio é inverso, imperando a presunção de inocência em favor do indivíduo/agente público.

Somente prova robusta é que poderá elidir a presunção de inocência,

\footnotetext{
24 "O 'enriquecimento presumido' do art. 9० , inc. VII, é comando direcionado primeiramente à autoridade que investiga. Se há desproporção entre o valor de um bem adquirido pelo agente público e a evolução de seu patrimônio, ou renda, há sérios indícios de improbidade, não culpa presumida" (SAMPAIO, José Adércio Leite. A Probidade na Era dos Desencantos. Crise e Propostas de Restauração da Integridade Dogmática da Lei no 8.429/92. In: ___ (Org.) [et al.]. Improbidade Administrativa: 10 Anos da Lei $n^{\circ}$ 8.429/92. Belo Horizonte: Del Rey, 2002. p. 176).
} 
onde a materialidade e a autoria da conduta ilícita estiverem invencivelmente caracterizadas, decorrente de ato ilícito do agente público, praticado no exercício da função.

O nexo de causalidade terá que estar presente, proveniente do enriquecimento ilícito do agente público vinculado ("em razão") única e exclusivamente a função pública, sem presunções ou dúvidas.

O dano não se presume, e muito menos o enriquecimento ilícito, pois exigem a necessidade, como dito anteriormente da figura do empobrecido.

A lesividade ao erário público decorre da prática de um ato ilícito, e não da presunção do mesmo. ${ }^{25}$

É juridicamente impossível estimar-se um dano decorrente da presunção de que houve enriquecimento ilícito do agente público. O enriquecimento ilícito deve estar inequivocamente presente no âmago do ato ilícito, tanto no tipo objetivo quanto no tipo subjetivo.

De igual forma sem a demonstração do nexo de causalidade, não há que se falar em enriquecimento ilícito do agente público.

A lesividade presumida no âmbito pecuniário, mercê da lesividade à ordem jurídica, é aquela que onera, sem benefícios, o erário público, em proveito próprio do agente público que deu causa ao ilícito.

É essencial, portanto, que restem provados três requisitos simultâneos: a ilegalidade do ato impugnado, a lesão aos cofres públicos e o enriquecimento ilícito do agente público. ${ }^{26}$

O agente público não se enriquece aleatoriamente, para tanto é necessário a prática de um ato lesivo ao erário público, salvo casos de enriquecimento não doloso, v.g., recebimento de uma herança, doação, dividendos em ações ou empresas em que ele é cotista, etc.

Neste sentido, tem-se a síntese do Des. Fed. Olindo Menezes: ${ }^{27}$ “(...) 1 - A Lei no 8.429/92, de 02.06.1992, alude à indisponibilidade cautelar de 'bens que assegurem o integral ressarcimento do dano', no caso, de lesão ao patrimônio público, ou 'acréscimo patrimonial resultante do enri-

\footnotetext{
25 "Ação Popular. Procedência. Pressupostos. Na maioria das vezes, a lesividade ao erário público decorre da própria ilegalidade do ato praticado. Assim o é quando dá-se a contratação, por município, de serviços que poderiam ser prestados por servidores, sem a feitura de licitação e sem que o ato administrativo tenha sido precedido da necessária justificativa" (STF. Rel. Min. Marco Aurélio, RE n 160381/SP, 2 ${ }^{a}$ T., DJ de 12 ago. 1994. p. 20052).

${ }^{26}$ Em um caso análogo ao que acabamos de afirmar, o TRF-2 ${ }^{a}$ Região na Ap. Cível n 319219/RJ, estabeleceu: "(...) 6 - Em relação à lesão aos cofres públicos, não restou claro que existiu qualquer irregularidade nos procedimentos licitatório e contratual, em ordem a se admitir que estar-se-ia diante de um caso de lesividade legalmente presumida" (TRF-2ª Região. Rel. Des. Fed. Arnaldo Lima, Ap. Cível nº 319219/RJ, 4ª T., DJ de 17 maio 2004. p. 295).
} 
quecimento ilícito', na hipótese de enriquecimento ilícito (art. $7^{\circ}$, parágrafo único), mas em qualquer das hipóteses, é indispensável que haja razoável demonstração dos supostos danos, ou do enriquecimento sem causa; enfim, de indícios veementes de responsabilidade (...)." [aspas no original].

Ou, segundo o Des. Fed. Tourinho Neto:28 “(...) 1 - O enriquecimento ilícito se dá com o que se obteve com a prática dos atos de improbidade. Perde-se o que ganhou ilicitamente (...)"

Como visto, o dano não se supõe, ou ele é decorrente de um ato ilegal, ou não há que se falar em enriquecimento ilícito presumido, visto que o caput do artigo $9^{\circ}$, da presente Lei estabelece o tipo legal vinculado ao exercício da função ou do cargo público do agente, o que significa dizer que ele deverá estar inequivocamente demonstrado e não presumido, sendo que: "A responsabilidade pelo ressarcimento deve ser proporcional aos atos praticados pelo causador do dano." 29

A improbidade administrativa, mais do que um ato ilegal, pressupõe, necessariamente, a falta de boa-fé, através de um ato desonesto, ${ }^{30}$ ou amoral, que deverá estar devidamente comprovado, visto ser defeso a sua presunção, em face da inversão do princípio onde o ônus da prova é do poder público e não do acusado, que constitucionalmente é inocente, até que se demonstre ao contrário.

Ratificando o que foi dito, muito próprio foi o julgado do TJ/MG que afastou a indenização sobre "suposto/remoto dano ao erário": "Indenização. Suposto/Remoto dano. Improcedência. Não se indeniza suposto dano ou dano remoto, incerto e eventual, mas somente aqueles diretos e efetivos, decorrentes, imediatamente, do ato omissivo/comissivo, culposo ou doloso imputado a outrem e cuja prova incumbe ao prejudicado demonstrar." ${ }^{1}$

Somente possui direito a uma reparação ou indenização aquele sujeito público ou privado que demonstre um prejuízo decorrente de um dano indevidamente praticado por terceiros. A presunção de um enriquecimento ilícito ou de um suposto dano agride ao direito, que não permite este tipo de situação, afastando-a em prol da segurança jurídica.

A condenação ao ressarcimento de danos ao erário exige a prova do efetivo prejuízo, que não é presumido, e sim certo e líquido. ${ }^{32}$

\footnotetext{
27 TRF-1 ${ }^{\text {a }}$ Reg. Rel. Des. Fed. Olindo Menezes, Al n 2004.01.000299245/DF, $3^{a}$ T., DJ de 8 abr. 2005. p. 33.

${ }^{28}$ TRF-1 ${ }^{a}$ Reg. Rel. Des. Fed. Tourinho Neto, Al n² 2003.01.000135935/GO, $2^{a}$ T., DJ de 30 out. 2003. p. 71.

${ }^{29}$ TRF-1 ${ }^{a}$ Reg. Rel. Des. Fed. Tourinho Neto, 2003.01.000099819/GO, 2a T., DJ de 25 set. 2003. p. 52.

${ }^{30}$ Cf. STJ. Rel. Min. Luiz Fux, Resp. n 480387/SP, $1^{\text {a }}$ T., DJ de 24 maio 2004. p. 163.
} 
Entendemos ser esse o melhor caminho, pois não é vedado, pela lei, que o servidor público, regido pela Lei no $8.112 / 90$, possa ser acionista, cotista ou comanditário de empresa privada, consoante determinação expressa do art. 117, X, do citado estatuto, verbis: "Art. 117. Ao servidor é proibido: (...) X - participar de gerência ou administração de sociedade privada, personificada ou não personificada, salvo a participação nos conselhos de administração e fiscal de empresas ou entidades em que a União detenha, direta ou indiretamente, participação no capital social ou em sociedade cooperativa constituída para prestar serviços a seus membros, e exercer o comércio, exceto na qualidade de acionista, cotista ou comanditário; (Redação dada pela Lei no 11.094, de 14.01.2005).”

Por outro lado, esta proibição não se aplica aos servidores que optarem, na forma do art. $17, \S \S 1^{\circ}$ e $2^{\circ}$, da Medida Provisória $n^{\circ} 2.174 / 2001$, pela redução da carga horária, desde que haja compatibilização de horário.

Onde estaria o enriquecimento ilícito do agente público se ele estivesse dentro das situações estipuladas no multicitado art. 117, da Lei $\mathrm{n}^{\mathrm{o}} 8.112 / 90$ ?

A Lei de Improbidade Administrativa não proíbe a ascensão lícita financeira/patrimonial do agente público, mas sim a sua finalidade é combater os atos ilegais que importaram enriquecimento ilícito.

Outra situação, que aliás é freqüente, é quando o agente público possui conta- corrente conjunta com seu cônjuge, companheiro(a) ou filho(a) e eles não são funcionários públicos. Nesses casos, poderá ocorrer uma movimentação bancária superior à recebida pelo servidor, sem que haja necessariamente subsunção de sua conduta no presente inc. VII do art. $9^{\circ}$, da Lei de Improbidade Administrativa. Deverá ser provado, pelo Poder Público, como já dito, que o agente público enriqueceu ilicitamente. Do contrário, a acusação é acéfala.

Neste sentido, Marino Pazzaglini Filho afirma: ${ }^{33}$ "A meu ver, data

\footnotetext{
${ }^{31}$ TJ/MG. Rel. Des. Geraldo Augusto, Ap. Cível n 1.0137.03.900294-4/001, $1^{\text {a } ~ C C, ~ D J ~ d e ~} 4$ jun. 2004.

${ }^{32}$ Ação civil pública. Ato ilegal. Ressarcimento ao erário. Lesividade. Ex-administrador. A reparação de dano decorre da comprovada lesividade material causada ao patrimônio público pelo ato ilegal do exadministrador. Se o ato impugnado não contém o ingrediente da lesividade, ainda que ilegal, não enseja o ressarcimento ao erário ou a procedência da ação civil pública, tendo por objeto o referido ressarcimento" (TJ/MG. Rel. Des. Almeida Melo, Ap. Cível no 163.442-7, 4a CC, DJ de 15 fev. 2000). No mesmo sentido: "Administrativo. Ação civil pública de reparação de danos ao erário. Prova da existência de dano efetivamente configurado. Princípios da razoabilidade e da proporcionalidade. Violação. Inteligência da Lei n 8.429/ 92. A procedência da ação civil pública de ressarcimento de danos ao erário está condicionada a prova da existência do dano efetivamente configurado, sob pena de violação dos princípios da razoabilidade e proporcionalidade, na forma da Lei de Regência" (TJ/MG. Ap. Cível n 1.0433.04906-7/001, 5a CC, DJ de 19 mar. 2004).
} 
venia, incumbe, na ação civil de improbidade, a seu autor provar que o agente público adquiriu valores incompatíveis com a evolução de seu patrimônio e rendimentos em decorrência do exercício abusivo, corrompido, subvertido de seu mandato, cargo, emprego ou função pública.”

Não há, na espécie, qualquer previsão legal, explicitamente, de inversão do ônus da prova. E sua adoção, por ser excepcional e afastar a regra processual geral actori encumbit probatio, tem que ser expressa e não tácita ou presumida.

Ademais, o art. $9^{\circ}$, da Lei $n^{\circ} 8.429 / 92$, do qual o 'enriquecimento sem causa' é uma das espécies em exame, trata de enriquecimento indevido, sem causa lícita, em razão do exercício da função pública. Assim, não é qualquer causa lícita de acréscimo patrimonial desmedido, mas decorrente do uso indevido da atividade pública para se enriquecer, que configura tal ato de improbidade administrativa.

Benedicto de Tolosa Filho ${ }^{34}$ faz, com muita propriedade, a devida distinção entre a diferença do enquadramento legal do acréscimo patrimonial para o Direito Tributário e para a Lei de Improbidade Administrativa, sublinhando a necessidade de uma prova contundente do Poder Público contra o agente público, para que não haja a indevida inversão do ônus da prova: "O cerne da ação que tipifica ato de improbidade administrativa é o aumento pessoal de patrimônio ou a aquisição disfarçada para terceiros de bens de qualquer espécie, desde que por agente público, no exercício do mandato, cargo, emprego ou função pública, cujo valor não guarde proporção com renda auferida. Para que o fisco inicie procedimento na área tributária, basta virem à luz os chamados 'sinais exteriores de riqueza', cabendo ao averiguado provar que os ditos 'sinais' são compatíveis com seus rendimentos. Essa premissa precisa ser tomada com o devido cuidado, quando transposta para a esfera dos atos de improbidade administrativa, sob pena de consagração da inversão do ônus da prova. Se na esfera tributária a presunção é suficiente para desencadeamento de procedimento averiguatório, para apuração de eventual ato de improbidade administrativa mister se faz que o autor da ação civil comprove que o patrimônio do agente público é incompatível, decorrente do exercício de mandato, cargo, emprego ou função pública. A inversão do ônus da prova, embora possa parecer clara pela redação do inciso analisado, deve ser

\footnotetext{
33 PAZZAGLINI FILHO, Marino. Lei de Improbidade Administrativa Comentada. São Paulo: Atlas, 2002. p. 66.

34 TOLOSA FILHO, Benedicto de. Comentários à Lei de Improbidade Administrativa. Rio de Janeiro: Forense, 2003. p. 80-81.
}

A \& C R. de Dir. Administrativo e Constitucional, Belo Horizonte, ano 6, n. 24, p. 97-140, abr.jun. 2006 
afastada em homenagem ao próprio fundamento do Estado Democrático de Direito. O nexo causal de ato de aumento patrimonial indevido pelo exercício de mandato, cargo, emprego ou função pública, deve ser demonstrado cabalmente pelo autor da ação civil pública." [aspas no original].

Para a tipificação do inciso em questão, é necessária a configuração do enriquecimento ilícito com o exercício de cargo, mandato, função, emprego ou atividades nas entidades públicas. Este é o nexo de causalidade, sem o qual ficará esfacelado qualquer tipo de subsunção no presente dispositivo legal: "O inc. VII é extensão e exemplificação do caput, denunciado pelo uso do advérbio notadamente. Este, ao conceituar o enriquecimento ilícito, refere-se a 'qualquer tipo de vantagem patrimonial indevida em razão do exercício de cargo, mandato, função, emprego ou atividade nas entidades', o que leva à inexorável conclusão de que deve ser evidenciado o nexo etiológico entre o enriquecimento e o exercício público, ou seja, que a causa do enriquecimento é ilícita porque decorre do tráfico da função pública. Portanto, para a caracterização dessa modalidade de enriquecimento ilícito é imprescindível que a aquisição de valores incompatíveis com a receita do agente público tenha ocorrido em decorrência do subvertido exercício de cargo, mandato, função, emprego ou atividade na Administração Pública direta, indireta, fundacional ou nas entidades a que se refere o art. $1^{\circ}$ da Lei Federal $n^{\circ} 8.429 / 92 . "{ }^{35}$ [aspas no original].

E mais à frente dize o ilustre publicista: ${ }^{36}$ "Tendo em vista as rigorosas sanções estipuladas no diploma em questão e sua repercussão na esfera privada e, levando-se em conta que sua aplicação conduz ao desapossamento de bens, à privação de direitos políticos e à interdição para o exercício de função pública, quer dizer, na privação de direitos fundamentais garantidos pela CF, não se pode aceitar a tese da presunção da ilicitude do enriquecimento calcada em também presumida, genérica e vaga improbidade administrativa. No Estado Democrático de Direito é inconcebível exigir do cidadão que prove que é inocente."

A figura do enriquecimento ilícito presumido é danosa, pois muitas injustiças poderão vir à tona se manejada a ação de forma abusiva ou precipitada, tendo em vista a amplitude da norma, que é bem aberta.

35 SAMPAIO, José Adércio Leite. A Probidade na Era dos Desencantos. Crise e propostas de restauração da integridade dogmática da Lei no 8.429/92. In: ___org.) [et al.]. Improbidade Administrativa: 10 Anos da Lei $n^{\circ} 8.429 / 92$. Belo Horizonte: Del Rey, 2002. p. 166.

${ }^{36}$ SAMPAIO, José Adércio Leite. A Probidade na Era dos Desencantos. Crise e propostas de restauração da integridade dogmática da Lei n 8.429/92. In: ___ (Org.) [et al.]. Improbidade Administrativa: 10 Anos da Lei $n^{\circ} 8.429 / 92$. Belo Horizonte: Del Rey, 2002. p. 71.

A \& C R. de Dir. Administrativo e Constitucional, Belo Horizonte, ano 6, n. 24, p. 97-140, abr.jun. 2006 
Em crítica aberta a esta elasticidade do inc. VII, do art. $9^{\circ}$, da Lei de Improbidade Administrativa, o Procurador da República de MG, Dr. José Adércio Leite Sampaio, ${ }^{37}$ deixou registradas inconsistências sintáticas: "Assim, por exemplo, o art. 9, inc. VII, cria a figura do 'enriquecimento ilícito presumido’, ao qualificar como improbidade a aquisição, para si ou para outrem no exercício de mandato, cargo, emprego ou função pública, de bens de qualquer natureza cujo valor seja desproporcional à evolução do patrimônio ou à renda do agente público. Haverá necessária vinculação entre a aquisição de um imóvel que tenha valor desproporcional à renda ou evolução patrimonial do agente público e as funções públicas desse agente? Se atentarmos para todo o art. $9^{\circ}$, veremos presente, para além de uma vantagem patrimonial indevida, o nexo entre a vantagem e a condição ou situação de agente público. O inc. VII silencia a esse respeito: será absoluta a presunção que estatui, ou haverá necessidade desse vínculo, transformando-se a presunção em relativa com ou sem a inversão do ônus da prova?"

Em seguida, o eminente Procurador da República arremata: "Se em vez de custos marginais pensarmos que as normas jurídicas são recortes lingüísticos, orientados por pressupostos comunicativos, para formação de consensos informados, chegaremos à mesma conclusão de falta de clareza e precisão do dispositivo."

Portanto, ilegal é a inversão do ônus da prova, pois o titular da ação pública deverá provar cabalmente que houve enriquecimento ilícito do agente público decorrente do exercício do seu mandato, cargo, função ou emprego. Sem essa prova, a ação judicial é natimorta, por faltar-lhe requisito essencial para a validade da lide, sendo a mesma inepta. ${ }^{39}$

Para a tipificação no presente inciso (VII, do art. $9^{\circ}$, Lei no 8.429/92), necessário se faz que haja a comprovação explícita de que o agente público, no exercício da função, se corrompeu ou aceitou rendimentos ou vantagens, para atuar em favor de terceiros. Esse liame - função pública e recebimento de vantagens econômicas - é de suma importância

\footnotetext{
37 SAMPAIO, José Adércio Leite. A Probidade na Era dos Desencantos. Crise e propostas de restauração da integridade dogmática da Lei n 8.429/92. In: __ (Org.) [et al.]. Improbidade Administrativa: 10 Anos da Lei $n^{\circ}$ 8.429/92. Belo Horizonte: Del Rey, 2002. p. 166.

38 SAMPAIO, José Adércio Leite. A Probidade na Era dos Desencantos. Crise e propostas de restauração da integridade dogmática da Lei n 8.429/92. In:___(Org.) [et al.]. Improbidade Administrativa: 10 Anos da Lei $n^{0}$ 8.429/92. Belo Horizonte: Del Rey, 2002. p. 166.
} 
para a subsunção da conduta do agente público no dispositivo sub oculis.

Pode ocorrer o caso de um agente público que invista na Bolsa de Valores ou ganhe um bilhete premiado da loteria, que certamente teria movimentação bancária desproporcional à renda recebida por exercer a função pública.

Por igual, se o agente público recebesse uma herança ou vendesse um imóvel, também estaria configurada movimentação da CPMF superior às remunerações recebidas de determinado ente de direito público.

Nestas situações, sobreleva salientar que o agente público não estaria transgredindo o disposto no inc. VII do art. $9^{\circ}$ da Lei de Improbidade Administrativa.

Este divisor se faz necessário, pois a letra da lei é clara em estipular que somente no exercício da função pública é que a aquisição de bens, aí se inclui, em sentido lato, depósito em dinheiro ou em títulos em bancos, recebidos pelo agente público, nessa qualidade é que serão responsabilizados. Sem esse liame, função pública e acréscimo patrimonial, não há que se falar em improbidade administrativa, pois a lei não pune quem licitamente alcança um rendimento maior/ ou bens móveis e imóveis, tendo em vista que o ilícito é a utilização da função pública para a obtenção de vantagem ilícita ligada ao oferecimento de uma contraprestação que impulsiona a evolução indevida do patrimônio ou da renda do agente público. Não poderá haver o dolo presumido, tendo em vista que os indícios/provas deverão levar à improbidade, como afirmado por José Adércio Leite Sampaio: ${ }^{40}$ "O 'enriquecimento presumido' do art. 9, inc. VII, é comando direcionado primeiramente à autoridade que investiga. Se há desproporção entre o valor de um bem adquirido pelo agente público e a evolução do seu patrimônio ou renda, há sérios indícios de improbidade, não culpa presumida." [aspas no original].

Demonstrada a licitude da evolução patrimonial ou de renda do servidor público cessa a justa causa da investigação, podendo-se falar inclusive em direito à obtenção de ressarcimento por danos morais e materiais em prol do servidor público — probo, é claro — processado por

\footnotetext{
39 Waldo Fazzio Junior pensa da mesma forma: "Se apenas com base na concomitância enriquecimento/ exercício do mandato o Ministério Público postular sua responsabilização por enriquecimento ilícito, estará formulando pedido absolutamente inepto, porque da premissa (enriquecimento) não se segue a conclusão (de que enriqueceu por abuso do cargo). Afinal, se da narração dos fatos não decorrer logicamente a conclusão incide a regra do art. 295, parágrafo único, inc. II. Fica faltando a conduta ilícita (ato de improbidade) que liga a premissa à conclusão, ou seja, a causa do enriquecimento, o abuso. Sem a declinação do ato antijurídico fica vazia a relação causal" (FAZZIO JUNIOR, Waldo. Improbidade Administrativa e Crimes de Prefeitos. 2. ed. São Paulo: Atlas, 2001. p. 8).
} 
mera emulação ou erro evidente.

\section{Ilegalidade de presumir-se depósito bancário como renda para fins de enriquecimento ilícito}

Na tentativa de caracterizar o enriquecimento sem causa do agente público, mesmo que não seja demonstrado um ato ilícito, ou prejuízo ao erário, tem sido muito comum para algumas Comissões de Processos Disciplinares quebrarem o sigilo bancário e fiscal, sem autorização judicial, agindo ilegalmente e maculando a prova, por colidir com o art. $5^{\circ}$, LVI, da CF, para que seja possível a utilização de valores correspondentes a depósitos ou saldos bancários a fim de configurar o indevido enriquecimento do investigado. Praticando inclusive desta forma a Comissão Disciplinar crime previsto na legislação.

A finalidade desse ilegal ato é caracterizar o depósito bancário como se fosse renda, mesmo que tal conclusão não possua suporte na legislação de regência.

O tributo em causa, como notoriamente sabido, possui como fato gerador, única e exclusivamente a aquisição de disponibilidade econômica ou jurídica, de renda ou proventos de qualquer natureza (Código Tributário Nacional, art. 43) ou seja, a aquisição da disponibilidade econômica ou jurídica: "Art. 43 (...) I - de renda, assim entendido o produto do capital, do trabalho ou da combinação de ambos; II - de proventos de qualquer natureza, assim entendidos os acréscimos patrimoniais não compreendidos no inciso anterior".

Neste sentido é pacífica a jurisprudência, seja no âmbito administrativo, seja no judicial.

Descabe, por conseguinte, cogitar-se da aquisição de disponibilidade jurídica ou econômica, de renda ou de proventos de qualquer natureza, pela simples constatação da realização de depósito em conta bancária pertencente ao contribuinte.

Os depósitos bancários, quando muito, podem, conforme já asseverado e demonstrado, em determinadas circunstâncias, configurar meros indícios da auferição de rendas ou de proventos de qualquer natureza. Inconcebível, entrementes, que tais depósitos, à falta da necessária aná-

\footnotetext{
40 SAMPAIO, José Adércio Leite. A Probidade na Era dos Desencantos. Crise e propostas de restauração da integridade dogmática da Lei no 8.429/92. In: ___ (Org.) [et al.]. Improbidade Administrativa: 10 Anos da Lei $n^{\circ} 8.429 / 92$. Belo Horizonte: Del Rey, 2002. p. 176.
} 
lise, da indispensável e convincente prova por parte do Fisco, sejam, por si só, presumidos como renda ou proventos para efeito de exigência de Imposto sobre Renda.

Ademais, a realização de depósito bancário pode advir de incontáveis fontes, sem que qualquer delas represente aquisição de disponibilidade econômica ou jurídica de renda ou de proventos.

E justamente por isso, a lei não ampara e jamais amparou a tributação pura e simples dos depósitos bancários, como quer fazer crer algumas Comissões Disciplinares.

Ausente de substrato legal, de há muito vêm sendo anulado pelo Poder Judiciário procedimentos que se baseiam única e exclusivamente em extratos bancários, originando a Súmula 182 do extinto TRF: "É ilegítimo o lançamento do imposto de renda arbitrado com base apenas em extratos ou depósitos bancários”.

Por outro lado, o próprio Poder Executivo promulgou o Decreto Lei $\mathrm{n}^{\circ}$ 2.471, de 01.09.88, que em seu art. $9^{\circ}$ prevê o cancelamento e arquivamento de procedimentos administrativos, que tomaram como base valores constantes de extratos ou de comprovantes de depósitos bancários. "Art. 9 ${ }^{\circ}$. Ficam cancelados, arquivando-se, conforme o caso, os respectivos processos administrativos, os débitos para com a Fazenda Nacional, inscritos ou não como Dívida Ativa da União, ajuizados ou não, que tenham tido origem na cobrança: (...) VII - do imposto de renda arbitrado com base exclusivamente em valores de extrato ou de comprovante de depósitos bancários.

A jurisprudência é pacífica no sentido de se anular lançamentos, arbitrados em extratos de contas-correntes bancárias, como se verifica no Acórdão no 89.01.20986-1 do Tribunal Regional Federal da $1^{\text {a }}$ Região que é assim ementado: "Decreto-Lei 2.471, VII, do art. 9º, Súmula 182 do TRF. 1 - O imposto de renda arbitrado, exclusivamente, com suporte em extratos de contas bancárias, já não encontra qualquer suporte legal após a edição do Decreto-Lei no 2.471, de 01.09.88, que com seu artigo $9^{\circ}$ do inciso VII, proibiu o lançamento do IR com base exclusiva nos extratos bancários. 2 - Anteriormente o TRF, na súmula no 1832, decidira: “É ilegítimo o lançamento do Imposto de Renda arbitrado com base apenas em extratos ou depósitos bancários. 3 - Remessa prejudicada por perda o objeto." ${ }^{41}$

Ives Gandra da Silva Martins,${ }^{42}$ com precisão, não deixou margem para qualquer dúvida sobre a matéria, acrescentando, in verbis: “(...) ainda 
hoje a Receita Federal autua pessoas com base nas contas bancárias, apesar da clareza da Súmula 182 do TRF que declara: É ilegítimo o lançamento do Imposto de Renda arbitrado com base apenas em extratos ou depósitos bancários." "Ref.: Lei 4.729, de 14.7.65, art. 9º , Decreto 58.400, de 10.5.66, art. 55, e 58 e 106, EAC 72.975-RJ ( $2^{\text {a }} \mathrm{S} 14.9 .82$ - DJ 4.11.82), EAC 80.623 $\operatorname{pr}\left(2^{\mathrm{a}} \mathrm{s} 4.9 .84\right), \mathrm{AC} 41.984-\mathrm{RJ}$ ( a $\mathrm{T}^{\mathrm{T}} 14.10 .81$ - DJ 05.11.81), REO 49.124-MG (5 $5^{\mathrm{a}} \mathrm{T} 16.8 .82$ - DJ 07.10.82), AC 51.591-SP (4 ${ }^{\mathrm{a}} \mathrm{T} 24.11 .82$ - DJ 04.04.83), REO 78.948-SP (4 $4^{\text {a }}$ T 30.11.83). Segunda Seção 1.10.85"

A chamada omissão de receita decorrente de movimentação bancária sempre foi examinada com bastante cautela: porque deduzir de meros depósitos bancários - cujas origens podem ser mais variadas - não significa dizer que houve aumento de renda, ganho real de capital, ou seja, que um agente público teve rendimentos, cuja existência omitiu, sendo a toda evidência, mera presunção.

É evidente que o fato de ter o contribuinte depósitos em sua contacorrente bancária poderia ad argumentandum dar ensejo à apuração pelo fisco, mas o que não se pode admitir é que tal fato, por si só, seja bastante para constituir o crédito tributário, por se presumir tratar-se de rendimentos sem a efetiva comprovação. ${ }^{43}$

Portanto, os saldos ou os depósitos bancários em conta-corrente bancária de agentes públicos, até 27.12.96, não se prestam ao fim de possibilitar a subsunção de suas condutas no disposto do presente artigo $9^{\circ}$, VII, da Lei em comento. Sucede que, independentemente do período de investigação, se anterior a janeiro/97 ou posterior, para que ocorra a responsabilidade administrativa do agente público é necessário o nexo de causalidade entre a função exercida e o recebimento de vantagem indevida. O sinal exterior de riqueza ou a renda a descoberto, sem o liame necessário, como dito, com a função pública, gera indícios de responsabilidade tributária, diferentemente da responsabilidade administrativa.

Na esfera tributária houve alteração do estabelecido no Decreto-Lei $n^{\circ}$ 2.471/88, com a entrada em vigor da Lei n ${ }^{\circ}$ 9.430, de 27.12.96.

$\mathrm{O}$ art. 42 da aludida norma estabeleceu a presunção juris tantum

\footnotetext{
41 TRF-1 ${ }^{a}$ Reg. Rel. Des. Nelson Gomes da Silva, 4ª T., REO n 8901209861/MG, DJ 23 abr. 1990.

${ }^{42}$ MARTINS, Ives Gandra da Silva. As Inconstitucionalidades do Decreto n. 97.834/89. Repertório IOB, Jurisprudência, São Paulo, 1.255/89.

${ }^{43}$ Essa era também a linha de interpretação do Poder Judiciário, como se verifica: "Tributário. Imposto de Renda. Autuação com base apenas em extratos bancários. Impossibilidade. Súmula 182/TFR. 'É ilegítimo - lançamento do imposto de renda arbitrado com base apenas em extratos bancários' (Súmula 82/TFR)" (STJ. Rel. Humberto Gomes de Barros, RESP 238356/CE, $1^{\text {a }}$ T., DJ de 2 out. 2000. p. 147). "Processual Civil. Tributário. Auto de Infração. Levantamento baseado em extratos bancários. Inteligência do artigo $9^{\circ}$
} 
de caracterização de omissão de receita ou de rendimento ou depósito bancário em relação ao qual o contribuinte não comprove a origem dos recursos através de documentação hábil e idônea. "Art. 42. Caracterizamse também omissão de receita ou de rendimento os valores creditados em conta de depósito ou de investimento mantida junto a instituição financeira, em relação aos quais o titular, pessoa física ou jurídica, regularmente intimado, não comprove, mediante documentação hábil e idônea, a origem dos recursos utilizados nessas operações. $\S 1^{\circ} \mathrm{O}$ valor das receitas ou dos rendimentos omitido será considerado auferido ou recebido no mês do crédito efetuado pela instituição financeira. $\S 2^{\circ}$ Os valores cuja origem houver sido comprovada, que não houverem sido computados na base de cálculo dos impostos e contribuições a que estiverem sujeitos, submeterse-ão às normas de tributação específicas, previstas na legislação vigente à época em que auferidos ou recebidos. $3^{\circ}$ Para efeito de determinação da receita omitida, os créditos serão analisados individualizadamente, observado que não serão considerados: I - os decorrentes de transferências de outras contas da própria pessoa física ou jurídica; II - no caso de pessoa física, sem prejuízo do disposto no inciso anterior, os de valor individual igual ou inferior a $\mathrm{R} \$ 1.000,00$ (mil reais), desde que o seu somatório, dentro do ano-calendário, não ultrapasse o valor de $\mathrm{R} \$ 12.000,00$ (doze mil reais). (Alterado pela Lei $\mathrm{n}^{\circ} 9.481$, de 13.08.97). §4 $4^{\circ}$ Tratando-se de pessoa física, os rendimentos omitidos serão tributados no mês em que considerados recebidos, com base na tabela progressiva vigente à época em que tenha sido efetuado o crédito pela instituição financeira. $§ 5^{\circ}$ Quando provado que os valores creditados na conta de depósito ou de investimento pertencem a terceiro, evidenciando interposição de pessoa, a determinação dos rendimentos ou receitas será efetuada em relação ao terceiro, na condição

do Decreto-Lei no 2.471/88. Aplicação da Súmula 182 do extinto TFR. Precedentes do STJ e TRF. 1. O artigo $9^{\circ}$ do Decreto-Lei $n^{\circ} 2.471$, de $1^{\circ}$ de setembro de 1988 , dispõe que é descabido o lançamento do Imposto de Renda com base exclusiva nos extratos bancários, como também, autoriza o cancelamento dos débitos para com a União (Fazenda Nacional) enquadrados nessa hipótese. 2. O enunciado da Súmula $n^{\circ} 182$ do extinto Tribunal Federal de Recursos preceitua que é ilegítimo o lançamento do Imposto de Renda arbitrado com base apenas em extratos ou depósitos bancários. Precedentes. 3. Apelação e remessa oficial desprovidas." "Processo civil. Tributário. Auto de infração. Omissão de receita. Levantamento baseado em Depósito Bancário. Aplicação da Súmula 182 - TFR. 1. O auto de infração que se fundamenta apenas na presumida disponibilidade financeira da empresa, derivada de depósitos bancários tidos como rendimentos omitidos, não encontra amparo no ordenamento jurídico vigente. 2. A simples demonstração de depósitos bancários não enseja nexo de causalidade entre o aumento patrimonial e a obrigação tributária. 3. O enunciado da Súmula $n^{\circ} 182$ do extinto Tribunal Federal de Recursos preceitua que é ilegítimo o lançamento do Imposto de Renda arbitrado com base apenas em extratos ou depósitos bancários. Precedentes. 4. Apelação provida" (TRF-1a Reg. Rel. Juiz Conv. Wilson Alves de Souza, ap. Cível n 93.01.119773/PA, 3ª T. Suplementar, DJ de 11 nov. 2004. p. 101). 
de efetivo titular da conta de depósito ou de investimento. (Incluído pela Lei $\mathrm{n}^{\circ} 10.637$, de 2002). $\S 6^{\circ} \mathrm{Na}$ hipótese de contas de depósito ou de investimento mantidas em conjunto, cuja declaração de rendimentos ou de informações dos titulares tenham sido apresentadas em separado, e não havendo comprovação da origem dos recursos nos termos deste artigo, o valor dos rendimentos ou receitas será imputado a cada titular mediante divisão entre o total dos rendimentos ou receitas pela quantidade de titulares. (Incluído pela Lei no 10.637 , de 2002)".

Por esta nova sistemática legal operou-se uma significativa mudança no tratamento tributário concernente à movimentação bancária dos contribuintes de imposto de renda, invertendo-se, com isto, o ônus da prova, visto que o titular da conta bancária passou a ter o ônus de provar que valores creditados em suas contas correntes-bancárias não se referem a receitas omitidas, sob pena de sujeitarem a autuação do fisco por acréscimo patrimonial a descoberto.

Sucede que as pessoas físicas estão desobrigadas de escrituração contábil, o que por si só gera um complicador para o contribuinte, que geralmente faz a sua declaração de imposto sobre renda levando em consideração as correspondentes informações anuais de renda fornecidas pelas instituições bancárias.

O destaque de um ou de mais valores depositados em determinados períodos na conta do contribuinte, acarreta na necessidade do depositante encontrar a boa vontade e presteza do banco depositário, visto que o mesmo (contribuinte) não é obrigado a guardar estes dados em seu poder, por já ter apresentado, em seu ajuste na declaração anual de imposto sobre renda os valores relativos aos respectivos saldos globalmente.

Portanto, para que o depósito bancário se transforme em renda tributável, é necessário que seja comprovada a utilização dos valores depositados como renda consumida (ex: aplicações em imóveis, carros e outros bens próprios ou benefício pessoal do contribuinte).

Terá que ficar comprovado o nexo de causalidade entre o depósito e o fato que represente omissão de rendimentos. ${ }^{44}$

No procedimento fiscal tributário para haver a autuação, com base em depósito bancário, nos termos do artigo 42, da Lei no 9.430/96, como já dito alhures, "não basta a simples presunção legal de que os depósitos constituem renda tributável, é imprescindível que seja comprovada a utilização dos valores depositados como renda consumida, evidenciando sinais exteriores de riqueza, visto que, por si só, depósitos bancários não A \& C R. de Dir. Administrativo e Constitucional, Belo Horizonte, ano 6, n. 24, p. 97-140, abr.jun. 2006 
constituem fato gerador do imposto de renda pois não caracterizam disponibilidade econômica de renda e proventos. O lançamento assim constituído só é admissível quando ficar comprovado o nexo causal entre o depósito e o fato que represente omissão de rendimentos." ${ }^{45}$

Assim, o depósito bancário, mesmo após o advento da Lei no 9.430/96, não se constitui, por si só, fato gerador da aquisição da disponibilidade econômica ou jurídica de renda ou de proventos de qualquer natureza, pois é necessária a prova cabal e robusta de que ele foi utilizado como renda consumida. Isto porque, a posse de numerário alheio, como por exemplo, descaracteriza a respectiva presunção de disponibilidade econômica.

Para ser tributado pelo imposto sobre renda, a disponibilidade econômica deve ser adquirida pelo contribuinte, não se cogitando, sob o prisma legal, a sua incidência se houver apenas a potencialidade de se adquirir a respectiva disponibilidade, ou se ela pertence a terceiros. Continua eficaz juridicamente o preceito que não se pode irrogar a presunção de que o cidadão é infrator de leis, sem que haja amparo em sólidas razões, precedidas de robustas provas, sobre fatos e dados bancários do contribuinte, que caracterizem a aquisição de renda tributável. Pois, "não há, no Estado de Direito, culpados por presunção." 46

Nem todo o ingresso financeiro constitui-se em acréscimo patrimonial, sendo necessário se verificar cada caso concreto.

Corroborando o que foi dito, o eminente Leandro Paulesen ${ }^{47}$ aduz: "Sendo o acréscimo patrimonial o fato gerador do Imposto de Renda, certo é que nem todo o ingresso financeiro implicará a sua incidência. Tem-se que analisar a natureza de cada ingresso para verificar se realmente se trata de renda ou proventos novos, que configurem efetivamente acréscimo patrimonial."

Pois bem, no caso da improbidade administrativa há que se fazer um divisor entre a presunção de omissão de receita na área tributária e a

\footnotetext{
${ }^{44}$ Nesse sentido, segue o entendimento do Conselho de Contribuintes: "Omissão de Rendimentos. Sinais Exteriores de Riqueza. Lançamento com Base em Depósito Bancário. No arbitramento, em procedimento de Ofício, efetuado com base em depósito bancário, nos termos do artigo 42 da Lei n 9.430/96, de 27.12.96, não basta a simples presunção legal de que os depósitos constituem renda tributável, é imprescindível que seja comprovada a utilização dos valores depositados como renda consumida, evidenciando sinais exteriores de riqueza, visto que, por si só, depósitos bancários não constituem fato gerador do imposto de renda pois não caracterizam disponibilidade econômica de renda e proventos. 0 lançamento assim constituído só é admissível quando ficar comprovado o nexo causal entre o depósito e o fato que represente omissão de rendimentos. Recurso provido" (Recurso no 133.413, 2 ${ }^{a}$ T/DRJ Curitiba/PR, Rel. Cons. Maria Goretti de Bulhões Carvalho, Acórdão n 102.46.139).

${ }^{45}$ Conselho de Contribuintes. Processo no 10660.004988/202-36, Recurso no 134.847, 4 $4^{\mathrm{a}}$ T/CRJ - Juiz de Fora, Rel. Cons. Maria Goretti Bulhões Carvalho, Sessão de 28 jan. 2004, Acórdão nº 102-46.231.
} 
presunção de enriquecimento ilícito defendida por alguns doutrinadores e aplicada por inúmeras Comissões Disciplinares de Inquérito.

Na primeira situação legal, presunção de omissão de receita, basta para o fisco a aparência de "sinais exteriores de riqueza" que o procedimento tributário é instaurado para que o contribuinte demonstre que a investigação é improcedente ou são compatíveis com os seus rendimentos os respectivos "sinais".

Antonio Airton Ferreira, ${ }^{48}$ louvando-se das lições de Aires Fernandino e Cléber Giardino, com perfeição esclarece que "a caracterização do sinal de riqueza, para fins de descoberta do sinal exterior de riqueza, depende de vários requisitos, que os depósitos bancários, por si só, não satisfazem, a saber: perfeita identificação do sinal; fixação da renda tributável relacionada com o sinal; demonstração da natureza tributável do rendimento; demonstração de que tal renda já não foi tributada."

Com o mesmo brilho, o Ministro Carlos Velloso, ${ }^{49} \mathrm{em}$ sede doutrinária, reforça a opinião que o sinal exterior de riqueza verificado pelos depósitos bancários, representam o marco inicial da investigação tributária, devendo evidenciar a renda consumida pelo contribuinte: "É que o sinal exterior de riqueza — os depósitos bancários, que evidenciariam a renda auferida ou consumida pelo contribuinte - deve ser o marco inicial da investigação do Fisco, com vistas a comprovar que o contribuinte teve o seu patrimônio aumentado sem a necessária declaração dos rendimentos, não sendo possível aceitar-se aquilo que deve ser o marco inicial da investigação com o seu ato final. Noutras palavras, não é possível acolher o procedimento do Fisco, que, diante dos depósitos bancários, tem como finda a investigação e faz incidir a tributação sobre tais depósitos. Se esse procedimento fosse aceito, o ponto inaugural da investigação fiscal acabaria se transformando no ato final, o que não é admissível.”

Se na esfera tributária existe a discricionariedade ampla do fisco em promover a devida investigação partindo da premissa de uma presunção de variação patrimonial a descoberto através dos "sinais exteriores de riqueza”, no direito administrativo tal presunção, vinculada a depósitos

\footnotetext{
${ }^{46}$ MELLO, Celso Antônio Bandeira de. Imposto sobre a Renda: Depósitos Bancários: Sinais Exteriores de Riqueza. Revista de Direito Tributário, São Paulo, n. 23-24, p. 101.

47 PAULESEN, Leandro. Direito Tributário: Constituição e Código Tributário à Luz da Doutrina e da Jurisprudência. 7. ed. Porto Alegre: Livraria do Advogado, 2005. p. 775.

48 FERREIRA, Antonio Airton. Os Depósitos Bancários de Pessoas Físicas como Base para a Presunção Legal de Omissão de Rendimentos. Jus Navigandi, Teresina, ano 6, n. 52, nov. 2001. Disponível em: < http:// jus2.uol.com.br/doutrina/texto.asp?id=2344>. Acesso em: 07 abr. 2006.

${ }^{49}$ VELloSO, Carlos Mário da Silva. Temas de Direito Público. Belo Horizonte: Del Rey, 1997. p. 378.
} 
bancários não é absoluta, pois não há a inversão do ônus da prova neste ramo do direito, visto que nesta situação jurídica a Administração Pública deverá provar que o agente público enriqueceu-se, com o aumento do seu patrimônio, de forma ilícita decorrente do exercício do seu cargo, emprego ou função pública. ${ }^{50}$

Aliás, este nexo de causalidade do enriquecimento ilícito é uma condicionante do próprio caput do art. $9^{\circ}$, da Lei $n^{\circ}$ 8.429/92, como já grafado anteriormente, que exige a auferição de qualquer tipo de vantagem patrimonial indevida vinculada diretamente ao exercício do munus público. Tal exigência legal retira a interpretação açodada de parte da doutrina de que no presente caso concreto pode-se presumir o enriquecimento ilícito com a simples verificação de uma evolução desproporcional do patrimônio ou da renda do agente público (inc. VII, do art. $9^{\circ}$ ), desatrelada do exercício do cargo, emprego ou da função pública.

Seria o mesmo que permitir que o inc. VII, alterasse o caput do art. $9^{\circ}$, ao qual ele está sistematicamente atrelado.

Sem o nexo de causalidade citado não há como transportar a presunção tributária para a lei de improbidade administrativa, ainda mais quando se verifica que na primeira situação legal poderá ocorrer um equívoco resultante de um ato culposo, ao passo que na derradeira situação (improbidade administrativa) ninguém se enriquece ilicitamente, senão através de um ato doloso, vinculado a uma conduta desonesta, através de má-fé praticada no exercício da função pública.

O que é defeso na Lei de Improbidade Administrativa é a auferição de vantagem patrimonial indevida, recebida através da prática de um ato de ofício ou de um ato omissivo, por parte do agente público. Se o agente público recebe valores ou possui aumento em seu patrimônio por ter auferido dividendos de ações, aplicações, distribuição de lucros em empresa que ele é cotista ou qualquer outro motivo que não se vincule ao exercício de sua função pública não se configura o tipo em questão, visto

\footnotetext{
${ }^{50}$ Pensa de modo igual Benedicto de Tolosa Filho: "Para que o Fisco inicie procedimento na área tributária, basta vir a luz os chamados 'sinais exteriores de riqueza', cabendo ao averiguado provar que os ditos 'sinais' são compatíveis com seus rendimentos. Essa premissa precisa ser tomada com o devido cuidado, quando transporta para a esfera dos atos de improbidade administrativa, sob pena de consagração da inversão do ônus da prova. Se na esfera tributária a presunção é suficiente para o desencadeamento de procedimento averiguatório, para apuração de eventual ato de improbidade administrativa mister se faz que o autor da ação civil comprove que o patrimônio do agente público é incompatível com seus rendimentos e que esse patrimônio sofreu alterações decorrentes do exercício do mandato, cargo, emprego ou função pública" (TOLOSA FILHO, Benedicto de. Comentários à Lei de Improbidade Administrativa. Rio de Janeiro: Forense, 2003. p. 80-81).
} 
que ele é fechado.

Tudo que não estiver contido nesse tipo não pode ser considerado como elemento integrante do que vem estabelecido no enriquecimento ilícito a que aduz o art. $9^{\circ}$, VII, da Lei no 8.429/92.

Além do mais, a presunção legal estabelecida na Lei $\mathrm{n}^{\circ}$ 9.430/96 só pode gerar efeitos previstos na esfera tributária, pois o artigo 110, do CTN, cujos preceitos são dirigidos primordialmente ao legislador ordinário, veda à legislação tributária alterar a definição, o conteúdo e o alcance dos institutos, conceitos e formas do direito privado para definir ou limitar competência da mesma.

Assim sendo, prevalece a ficção legal da hipótese do enriquecimento injusto nas disposições estabelecidas nos artigos 884 e seguintes do Código Civil, que claramente condicionam a restituição de valores recebidos indevidamente desde que eles sejam correlatos ao empobrecimento de outrem.

Aliás, a teoria do enriquecimento injusto foi incluída embrionariamente em texto do Digesto, atribuído a Pomponius (Lib. L, Tit. XVII, fra. 206) que dizia: Jure naturae aequun est neminem cum alterius detrimento et injuria fieri locupletiorem (Por direito da natureza é justo que ninguém se enriqueça com prejuízo e injúria de outrem). ${ }^{51}$

Portanto, também pela dicção do art. 110, do CTN, a presunção contida no art. 42, da Lei ${ }^{\circ}$ 9.430/96 não pode alterar o conceito de renda ou de provento para neles incluir depósitos bancários. Pode, quando muito, autorizar a tributação de tais depósitos por presunção, desde que verificado caso a caso, bem como se ocorreu a renda consumida.

Conseqüentemente, o CTN não autoriza que lei tributária amplie o conceito de renda e que este conceito ampliado seja aplicado em matéria vinculada ao direito administrativo.

O disposto no artigo 110, do CTN explicita "que o legislador não pode expandir o campo de competência tributária que lhe foi atribuído, mediante o artifício de ampliar a definição, o conteúdo ou alcance de institutos de direito privado utilizados para definir aquele campo." ${ }^{2}$

Por igual, Henry Tilbery ${ }^{53}$ também reforça a posição da doutrina que estabelece as limitações da aplicação na base de cálculo do imposto

\footnotetext{
${ }^{51}$ Cf. BARACHO, José Alfredo de Oliveira. O Enriquecimento Injusto como Princípio Geral do Direito Administrativo. Revista Forense, Rio de Janeiro, v. 347, p. 149, 1999.
}

A \& C R. de Dir. Administrativo e Constitucional, Belo Horizonte, ano 6, n. 24, p. 97-140, abr.jun. 2006 
de renda pelo montante arbitrado ou presumido, quando ele afirma: "De um lado a lei formal prevê a apuração do quantum tributável pelo imposto de renda como procedimento normal, com a colaboração do contribuinte, pela declaração dele, controlada pelo Fisco, porém permite, como método auxiliar, em determinados casos excepcionais (principalmente inadimplemento das obrigações acessórias pelo contribuinte), o processo indiciário. De outro lado, correspondendo fielmente a essas alternativas, a lei material autoriza a tributação por esse imposto, além da base de cálculo normal, que é o montante real da renda ou dos proventos tributáveis, também para auxiliar a Fazenda - sobre a base do montante arbitrado ou presumido. Vigora, todavia, uma limitação importante: jamais poderá o uso dos métodos complementares - presunção ou arbitramento - desvirtuar a natureza do imposto de renda! Portanto inadmissível qualquer interpretação da lei, que conduziria à fixação da matéria tributável pelo imposto de renda, por montante arbitrado ou presumido, em tal grandeza que ultrapassaria os limites do conceito do imposto de renda. José Luiz Bulhões Pedreira, como teste da constitucionalidade da lei ordinária do imposto de renda, coloca em relevo a compatibilidade com o conceito de renda tributável, e ao mesmo tempo salienta que esse critério vincula não somente o legislador na construção da lei, mas também o intérprete na exegese."

A seguir, o citado publicista ${ }^{54}$ tece os seguintes comentários sobre os freqüentes casos de tributação pelo imposto de renda de depósitos bancários: "Os freqüentes casos de tributação pelo imposto de renda de depósitos bancários são um outro exemplo, que deve ser mencionado no presente contexto. Quando os saldos bancários compõem um acréscimo patrimonial sem cobertura seja pelos rendimentos declarados seja por rendimentos não tributáveis, é legítima a imposição da Cédula $\mathrm{H}$, letra c do RIR. Porém já houve casos, quando depósitos bancários foram utilizados pelo Fisco como motivo de arbitramento a título de 'sinais exteriores de riqueza', como fundamento de tributação na Cédula $\mathrm{H}$, letra e, do RIR. Casos dessa natureza devem ser solucionados conforme os fatos específicos, porém, em princípio, 'depósitos bancários devidamente comprovados pela repartição fiscal' não são, por si, rendimento tributável; podiam ter outra origem, como transferência de capital e outros. E exatamente em casos desta natureza, quando no arbitramento dos rendimentos

52 AMARO, Luciano da Silva. Direito Tributário Brasileiro. 3. ed. São Paulo: Saraiva, 1999. p. 210.

53 TILBERY, Henry. Comentários ao Código Tributário Nacional. São Paulo: Saraiva, 2002. p. 347.

A \& C R. de Dir. Administrativo e Constitucional, Belo Horizonte, ano 6, n. 24, p. 97-140, abr.jun. 2006 
com base de sinais exteriores de riqueza, deve ser vigiada a obediência ao conceito de renda. (...) O dispositivo legal, introduzido como instrumento de combate, por meio de tributação por presunção, não deve conduzir nunca à ampliação do campo de incidência do imposto de renda, para incluir matéria estranha ao conceito de renda tributável, e sem qualquer correspondência econômica à distribuição de lucros." [aspas no original].

Portanto, verificam-se dois institutos de direito totalmente diversos, onde a área tributária admite a possibilidade jurídica da presunção de omissão de receita, ao passo que o direito administrativo para permitir que se presuma a hipótese de enriquecimento ilícito do agente público, com base em depósitos bancários não justificados ou desproporcionais à respectiva renda, tem que estar atrelado ao exercício irregular da função pública.

Assim, não há como se transportar à presunção tributária para a improbidade administrativa, pois nesta última situação jurídica vigoram justamente conceitos distintos e opostos àquela, visto que é aplicada a presunção de inocência, onde a Administração Pública possui o dever legal de demonstrar a ilicitude do acusado/investigado, através de ato desonesto, praticado no exercício da função pública.

Além do mais, a guisa de ilustração, se não fossem distintas as situações jurídicas narradas, seria ferido o princípio constitucional da isonomia (art. $5^{\circ}$, caput, da CF) entre agentes públicos e os contribuintes, visto que o indivíduo, ao obter acréscimos patrimoniais não justificados, não está sujeito ao perdimento dos bens assim adquiridos, e sim autuado para pagar o imposto de renda correspondente. Já não ocorre este tratamento com o agente público, que é obrigado a ressarcir integralmente o erário, apesar da origem jurídica ser a mesma (omissão de receita ou sinais exteriores de riqueza), tendo em conta que parte da doutrina estabeleceu a esdrúxula hipótese do enriquecimento ilícito presumido, por interpretar isoladamente a redação do inc. VII, sem conjugá-lo sistematicamente com o caput do seu artigo $9^{\circ}$, da Lei $\mathrm{n}^{\mathrm{o}}$ 8.429/92. O raciocínio do enriquecimento ilícito presumido está totalmente incorreto apesar de ser defendido por ilustres doutrinadores ao qual nutrimos o maior respeito e admiração, visto que é defeso pelo caput do art. $9^{\circ}$, da Lei de Improbidade Administrativa tal interpretação.

O enriquecimento ilícito foi discorrido, anteriormente, tanto na doutrina, como na legislação nacional, por Bilac Pinto, com análises sobre 54 TILBERY, Henry. Comentários ao Código Tributário Nacional. São Paulo: Saraiva, 2002. p. 347.

A \& C R. de Dir. Administrativo e Constitucional, Belo Horizonte, ano 6, n. 24, p. 97-140, abr./jun. 2006 
a intervenção do Estado na ordem econômica e suas repercussões, ocasião em que foi grafada a área sujeita à corrupção. Sendo estabelecido um parâmetro entre a corrupção e o enriquecimento ilícito no âmbito da política e na administração pública.

E coube à Constituição de 1946 estabelecer sanção para a corrupção política e administrativa (\$31, do art. 141, CF/1946), correspondente ao seqüestro e à perda dos bens e valores auferidos através de enriquecimento ilícito dos servidores públicos e dos empregados autárquicos.

A Lei $\mathrm{n}^{\mathrm{o}} 3.502$, de 21 de dezembro de 1958, em complemento ao texto constitucional, estabeleceu que: o servidor público, ou dirigente, ou empregado de autarquia, que, por influência ou abuso de cargo ou função se beneficiar de enriquecimento ilícito, ficará sujeito ao seqüestro e perda dos respectivos bens ou valores..$^{55}$

Desde o início, como não poderia deixar de ser, a doutrina dominante estabeleceu a necessidade do nexo de causalidade do enriquecimento ilícito com o exercício do cargo ou do emprego público.

Ao tratar do enriquecimento ilícito ou enriquecimento sem causa, no início do século XX o professor Valle Ferreira estabeleceu a essencialidade da relação de causalidade entre o aumento patrimonial e a diminuição do outro: ${ }^{56}$ "Não basta o aumento de um patrimônio e a diminuição de outro. É preciso que se verifique uma relação mútua entre os dois fenômenos, isto é: que o enriquecimento tenha resultado do empobrecimento. Esta correlação entre os dois fatos é essencial e constitui um dos pontos mais discutidos pelos autores. (...) A relação causal é indispensável para que se possa decidir se o aumento de um patrimônio foi devido à diminuição do outro; estabelecida tal relação, só se caracteriza o enriquecimento se, por sua vez, a transferência de valores ocorreu sem causa, vale dizer: sem razão, sem justificação."

No mesmo sentido, o professor José Alfredo de Oliveira Baracho, ${ }^{57}$ em belíssimo estudo sobre o tema sub oculis, expõe com acerto: "A aplicação do enriquecimento injusto, no âmbito das relações administrativas começou pelo reconhecimento de ações que visavam a conter abusos da Administração Pública. Como pressuposto do enriquecimento injusto, podemos entender que: configura-se o enriquecimento, quando surge uma vantagem patrimonial, que pode levar ao aumento do patrimônio (lucrum emergens) ao lado da diminuição do patrimônio (damnum cessans), ocorre o empobre-

\footnotetext{
55 PINTO, Francisco Bilac Moreira. Enriquecimento Ilícito no Exercício de Cargos Públicos. Rio de Janeiro: Forense, 1960. p. 133
}

A \& C R. de Dir. Administrativo e Constitucional, Belo Horizonte, ano 6, n. 24, p. 97-140, abr.jun. 2006 
cimento, representado por um dano, que se constitui em um damnum emergents e um lucrum cessans, de onde decorre o enriquecimento, sem causa justificadora do mesmo; inexiste preceito legal que exclua a aplicação do enriquecimento sem causa. Consagra a jurisprudência a aplicação de normas de eqüidade e proporcionalidade, proibidoras do enriquecimento à custa de outrem." [itálico no original].

Especificamente sobre o inc. VII, do artigo $9^{\circ}$, da Lei de Improbidade Administrativa, Benedicto de Tolosa Filho ${ }^{58}$ enaltece a necessidade do nexo de causalidade entre o enriquecimento ilícito e a prática de um ato administrativo irregular: "A inversão do ônus da prova, embora possa parecer claro pela redação do inciso analisado, deve ser afastada em homenagem ao próprio fundamento do Estado Democrático de Direito. O nexo causal do ato de aumento patrimonial indevido pelo exercício de mandato, cargo emprego ou função pública, deve ser demonstrado cabalmente pelo autor da ação civil pública."

Desta forma, a presunção de enriquecimento ilícito por aumento patrimonial injustificado viola a própria literalidade do inc. VII, do art. $9^{\circ}$, da Lei $\mathrm{n}^{\circ} 8.429 / 92$, em razão da necessidade do nexo de causalidade com o exercício do mandato, cargo, emprego ou função pública, expressamente determinado.

Interpretar de forma diversa imporia a conclusão de que, no caso do agente público, presume-se, implicitamente, ainda que sem efeito penal, que tal acréscimo patrimonial teve origem em algum crime contra a Administração Pública (peculato, corrupção, etc.) enquanto que, no caso do contribuinte do imposto sobre renda não existe a ilação que o acréscimo patrimonial teve origem em algum ilícito criminal (furto, estelionato ou outra fraude, etc.).

É muito comum o erro que a instância administrativa/disciplinar tem levado a efeito, inclusive como prática contumaz, pois mesmo ausente uma justa causa, pela falta de uma infração funcional, a Administração Pública, imprudentemente, vem indiciando servidores públicos em Procedimentos Administrativos Disciplinares por enriquecimento ilícito presumido, baseando-se, tão somente em valores constantes de extratos bancários, CPMF, etc.

\footnotetext{
${ }^{56}$ FERREIRA, José G. Valle. Enriquecimento sem Causa. Belo Horizonte: Liv. Oscar Nicolai, [199-?]. p. 141.

${ }^{57}$ BARACHO, José Alfredo de Oliveira. O Enriquecimento Injusto como Princípio Geral do Direito Administrativo. Revista Forense, Rio de Janeiro, v. 347, p. 153, 1999.

58 TOLOSA FILHO, Benedicto de. Comentários à Lei de Improbidade Administrativa. Rio de Janeiro: Forense, 2003. p. 81
}

A \& C R. de Dir. Administrativo e Constitucional, Belo Horizonte, ano 6, n. 24, p. 97-140, abr./jun. 2006 
O patrimônio a descoberto, por igual, também é distorcido, gerando pseuda responsabilidade administrativa funcional indevidamente.

É preciso que se estabeleça um divisor, pois as instâncias são independentes e uma variação patrimonial a descoberto ou até mesmo os depósitos bancários em conta- corrente, são, quando muito, ilícitos tributários, que deverão ser apurados no nível da Receita Federal, pois esta é que possui competência legal pela constituição e lançamento do crédito tributário e não a instância administrativa/disciplinar ou até mesmo o Poder Judiciário.

Em assim sendo, não existindo um ato funcional ilícito, praticado no exercício do vínculo público, não se configura a açodada subsunção da conduta no que vem descrito no art. $9^{\circ}$, VII, da Lei de Improbidade Administrativa.

Desta forma, a simples demonstração de depósitos bancários não dá azo a equivocada presunção de enriquecimento ilícito, visto ser necessário o devido nexo de causalidade ${ }^{59}$ entre o aumento patrimonial e a função pública, através de um ato de ofício comissivo ou omissivo. Sem esse imperioso requisito (nexo de causalidade), não há como se sustentar a prática do delito previsto no art. $9^{\circ}$, VII, da Lei de Improbidade Administrativa.

Isto porque, para que ocorra a subsunção da conduta no referido artigo, é necessário o elemento subjetivo do tipo, no caso o dolo, ao passo que a não inclusão como rendimentos tributários, na declaração do imposto sobre renda, de valores depositados em contas correntes ou em investimentos do contribuinte caracteriza fato simples de presunção de omissão de rendimentos, com o afastamento do dolo e sem a aplicação da multa qualificada.

A fraude não se presume, ela terá que ser provada, ${ }^{60}$ através dos meios legais próprios.

Sendo certo que a própria Receita Federal afasta o dolo da presunção legal dos depósitos bancários, sendo indevida a aplicação de multa qualificada de $150 \%$ aplicada de ofício. ${ }^{61}$

Não havendo a caracterização do dolo na instância tributária, e

\footnotetext{
59 "Processo civil. Tributário. Auto de infração. Omissão de Receita. Levantamento baseado em depósito bancário. Aplicação da Súmula 182-TFR. 1. O auto de infração que se fundamenta apenas na presumida disponibilidade financeira da empresa, derivada de depósitos bancários tidos como rendimentos omitidos, não encontra amparo no ordenamento jurídico vigente. 2. A simples demonstração de depósitos bancários não enseja nexo de causalidade entre o aumento patrimonial e a obrigação tributária. 3. O enunciado da
} 
sendo ele necessário para a tipificação do enriquecimento ilícito presumido, não há como subsumir a conduta do agente público no que vem estabelecido no art. $9^{\circ}$, VII, da Lei $n^{\circ} 8.429 / 92$.

Demonstrado, portanto, a grande incoerência jurídica de se transportar a presunção de depósitos bancários (omissão de receita) para a improbidade administrativa, com a inversão da presunção de inocência, como se fosse suficiente para configurar o enriquecimento ilícito, sem a inexistência de ato administrativo comissivo ou omissivo.

Tal presunção no campo sancionatório é terminantemente vedado.

Apesar da natureza da ação de improbidade ser cível, as penalidades cominadas na Lei no 8.429/92 possuem "nítida natureza penal ou punitiva”, conforme afirmou o Min. Nelson Jobim em seu voto na RCL no 2138-6, no sentido de que o Ministro de Estado e outras autoridades políticas sujeitas ao crime de responsabilidade não podem estar sujeitas à Lei de Improbidade Administrativa, por constituir-se em verdadeiro bis in idem.

A responsabilidade pela prática de um ato de improbidade administrativa, como não poderia deixar de ser é vinculada ao exercício da função pública. Mesmo que haja indícios de uma irregularidade tributária, capaz de demonstrar sinais exteriores de riqueza ou uma evolução patrimonial desproporcional, para que ocorra o devido reflexo na Lei $n^{\circ}$ 8.429/92 é necessário que a origem seja a atividade pública do agente investigado/ acusado.

\section{Quebra de sigilos bancário e fiscal do agente público não pode}

Súmula $n^{\circ} 182$ do extinto Tribunal Federal de Recursos preceitua que é ilegítimo o lançamento do Imposto de Renda arbitrado com base apenas em extratos ou depósitos bancários. Precedentes. 4. Apelação provida" (TRF. $1^{a}$ Reg., Rel. Juiz Fed. Conv. Wilson Alves de Souza, Ap. Cível nº 96.01.543465/ MG, $3^{a}$ T., Suplementar, DJ de 9 abr. 2004. p. 32).

${ }^{60}$ Cf. STF. RE n 39920, Rel. Min. Afrânio Costa, 2 a T., julgado em 18 out. 1956, Ementário vol. 284, p. 438.

61 "Prática de ato doloso. Qualificação da Multa. Prova - A falta de registro na declaração de ajuste anual de rendimentos considerados omitidos por presunção legal (depósitos bancários) não evidencia, por si só dolo do contribuinte a permitir aplicação de multa qualificada de 150\%, pelo que aplicável a multa de ofício. Recurso de ofício negado." (Conselho de Contribuintes. 6ª C., Processo 10945.003580/2003-31, Acórdão 10613818, data da sessão 18 fev. 2004). No mesmo sentido: "Multa de lançamento de Ofício qualificada - Justificativa para aplicação da multa - Evidente intuito de fraude - Qualquer circunstância que autorize a exasperação da multa de lançamento de ofício de 75\%, prevista como regra geral, deverá ser minuciosamente justificada e comprovada nos autos. Além disso, para que a multa de $150 \%$ seja aplicada, exige-se que o contribuinte tenha procedido com evidente intuito de fraude, nos casos definidos nos artigos 71, 72 e 73 da Lei $n^{\circ} 4.502$, de 1964. A falta de inclusão na Declaração de Ajuste Anual, como rendimentos, de valores que transitaram a crédito em conta corrente bancária pertencente ao contribuinte, cuja origem não comprove, caracterizam falta simples de presunção de omissão de rendimentos, porém, não caracteriza evidente intuito de fraude, nos termos do artigo 992, inciso II, do Regulamento do Imposto de Renda, aprovado pelo Decreto $n^{\circ} 1.041$, de 1994. Recurso de ofício negado" (Conselho de Contribuintes. $4^{a}$ C., Processo $n^{\circ}$ 10980.011423/2002-92, Rel. Cons. Nelson Mallmann, Acórdão n 104.19516, data da sessão 9 set. 2003).

A \& C R. de Dir. Administrativo e Constitucional, Belo Horizonte, ano 6, n. 24, p. 97-140, abr./jun. 2006 


\section{se dar sem motivo justificado e fundamentado}

Com muita freqüência, a Administração Tributária, detentora da guarda dos sigilos bancários (declaração sobre renda) tem fornecido dados, mesmo que sem autorização judicial de agentes públicos, para que o Poder Público/Administração Pública inicie investigação, por enriquecimento ilícito presumido.

Este ato é ilegal e fere Direito fundamental da proteção de sigilos de dados (art. $5^{\circ}$, X e XII, da CF) do agente público investigado.

Os Direitos fundamentais são "valores supremos" ${ }^{2}$ que possibilitam a garantia do status libertatis de toda sociedade, possuindo função social.

A ponderação dos Direitos fundamentais que a doutrina moderna tem admitido não pode chegar a medida de desnaturá-los.

Ou seja, a relativização dos direitos fundamentais da sociedade não pode retirar a função social dos mesmos, como aduz Peter Häberle: ${ }^{33}$ "La ya descrita 'función social' de los derechos fundamentales, su importancia para la vida social 'en su conjunto' pretendida por la Ley Fundamental con su garantía, tiene en el presente contexto un interés especial: también evita una 'relativización' de los derechos fundamentales. Se prohibe al legislador una puesta en peligno de la 'función social' de los mismos. No puede reulnerar el 'funcionalismo universal' de la libertad en la vida social ni el 'resultado colectivo' a que la Constitución aspira. Al contrario. El punto de mira del legislador cuando introduce normaciones en el ámbito de los derechos fundamentales tiene que se alcanzar un grado óptimo de la significación de los mismos para la vida social en su conjunto.” [aspas no original].

Não resta dúvida que a Constituição Federal estabelece princípios objetivos elencados no art. 37, que devem ser observados e cumpridos pelo Poder Público, sendo que um deles é o da impessoalidade, a exigir que não haja perseguições ou privilégios desarrazoados.

Pela imparcialidade é defeso ao Estado eleger seus agentes públicos para este ou aquele fim, visto que somente por um justo motivo é que poderá haver a devida investigação tributária/administrativa, pois "está vedado al Estado distinguir entre los indivíduos en función de su presunto

\footnotetext{
62 HÄBERLE, Peter. La Garantía del Contenido Esencial de Los Derechos Fundamentales. Tradução de Joaquín Brage Camazano. Madrid: Dykinson, 2003. p. 7.

${ }^{63}$ HÄBERLE, Peter. La Garantía del Contenido Esencial de Los Derechos Fundamentales. Tradução de Joaquín Brage Camazano. Madrid: Dykinson, 2003. p. 50.
} 
valor moral." ${ }^{64}$

O Estado Democrático de Direito começa a existir a partir da Constituição Federal que através de cláusulas garante a aplicação dos Direitos fundamentais, estabelecendo a devida e necessária segurança jurídica de todos.

E a aplicação dos princípios e normas constitucionais deve objetivar alcançar o equilíbrio entre a força do Estado colocada para bem servir ao indivíduo, e a manutenção dos direitos e das garantias fundamentais de uma sociedade livre, justa e solidária.

Tem-se, assim, que o agente público para ser alçado à condição de investigado, não poderá ser eleito por vontade pessoal de sua chefia ou política do órgão público, visto que pelo princípio da impessoalidade e outros, sua conduta deverá subsumir-se a um tipo legal, sob pena de configurar um abuso de poder investigatório da autoridade processante.

$\mathrm{O}$ resguardo de informações bancárias era regido pela Lei $\mathrm{n}^{\circ}$ 4.595/64, reguladora do Sistema Financeiro Nacional, e que foi recepcionado pelo art. 192, da Constituição Federal, com força de Lei Complementar, que possibilitava a quebra de sigilo bancário apenas por decisão judicial, até o advento da vigente Lei Complementar $n^{\circ}$ 105/2001.

Por outro lado, após a edição da Lei $n^{\circ}$ 9.311/96, que instituiu a CPMF, as instituições financeiras responsáveis pela retenção da referida contribuição, ficaram obrigadas a prestar informações à Secretaria da Receita Federal fornecendo dados a respeito de identificação dos contribuintes e os valores globais das respectivas operações bancárias.

A possibilidade de quebra do sigilo bancário foi levada a efeito pelo art. $6^{\circ}$, da Lei Complementar n ${ }^{\circ}$ 105/2001: "Art. 6 ${ }^{\circ}$. As autoridades e os agentes fiscais tributários da União, dos Estados, do Distrito Federal e dos Municípios somente poderão examinar documentos, livros e registros de instituições financeiras, inclusive os referentes a contas de depósitos e aplicações financeiras, quando houver processo administrativo instaurado ou procedimento fiscal em curso e tais exames sejam considerados indispensáveis pela autoridade administrativa competente.”

Como visto, para haver a quebra de sigilo bancário/fiscal na atualidade, deverá haver processo administrativo instaurado ou proce-

\footnotetext{
${ }^{64}$ BENDA, Ernest. Dignidad Humana y Derechos de la Personalidad. In: MANUAL de Derecho Constitucional. 2. ed. Madrid: Marcial Pons, 2001. cap. IV, p. 125.
}

A \& C R. de Dir. Administrativo e Constitucional, Belo Horizonte, ano 6, n. 24, p. 97-140, abr.jun. 2006 
dimento fiscal em curso, sendo certo que tais exames sejam considerados imperiosos e fundamentais pela autoridade administrativa competente. Esta autorização legal não serve como um poder para a Administração Pública, visto ser necessária a justa causa e a devida razoabilidade da medida. O que temos presenciado é justamente o contrário, onde o Poder Público primeiro acusa, depois tenta reunir provas, para após formalizar o procedimento administrativo solicitando autorização judicial para respaldar a já efetuada quebra de sigilos. ${ }^{65}$

A pretexto de possibilitar uma pseudo investigação do contribuinte/ agente público, o Poder Público tem vilipendiado os respectivos direitos de sigilo de dados, da intimidade, da privacidade, através da quebra do sigilo bancário/fiscal, sob o fundamento que está verificando se houve a prática de enriquecimento ilícito presumido, sem contudo, demonstrar um nexo de causalidade com a função pública. Ou seja, é invertida a presunção de inocência do agente público acusado, com a quebra de seus sigilos de dados, sem ao menos ser demonstrada uma violação a preceito administrativo, ou a prática de um ilícito por parte do mesmo. Deveria ser demonstrado, em primeiro lugar, a prática de um ilícito, vinculada a função pública exercida pelo agente público investigado, para após ser apurado se houve o enriquecimento ilícito presumido. A inversão destes papéis é extremamente danosa, pois a Administração Pública parte do princípio de que se houver uma movimentação bancária incompatível com os vencimentos do agente público resta caracterizado o enriquecimento ilícito presumido.

Como já aduzido anteriormente, a movimentação bancária não demonstra a aquisição de renda, sendo indevido o lançamento tributário baseado apenas em saldo bancário.

Além do mais, os valores depositados em conta-corrente bancária podem ser oriundos de movimentação lícita, tal como compra e venda de bens móveis, imóveis, recebimento de herança, contas conjuntas, doação, dividendos de empresas, ações, fundos de investimentos, etc.

\footnotetext{
${ }^{65}$ Miguel Reale e Ives Gandra da Silva Martins, com a precisão de sempre, já advertiam quanto ao que acabamos de aduzir: "Em outras palavras, se nos processos investigatórios o sigilo já estaria quebrado, por que solicitar ao Poder Judiciário autorização para obter informações que a própria Receita já estaria de posse..." (REALE, Miguel; MARTINS, Ives Gandra da Silva. Inconstitucionalidade do Decreto n 4.489 , de 28/11/2002 por macular o Processo Legislativo Plasmado na Lei Suprema e Infringir Direitos Fundamentais do Cidadão: Opinião Legal. Revista Ibero-Americana de Direito Público, Rio de Janeiro, ano 4, v. 9, p. 283, 1. trim. 2003)
}

A \& C R. de Dir. Administrativo e Constitucional, Belo Horizonte, ano 6, n. 24, p. 97-140, abr.jun. 2006 
Presumir a ilicitude ou a desproporcionalidade da movimentação financeira, sem um nexo de causalidade com a função pública configura uma indevida e injustificada quebra de sigilo de dados, visto que para ela ser considerada justificável deverá vir precedida de um motivo justificado e fundamentado, que possua ponto de apoio em um ato ilícito praticado no exercício da função pública.

E não basta a autoridade que investiga o agente público alegar que o motivo e o fundamento da quebra do sigilo é a verificação do aludido enriquecimento ilícito presumido do agente público, pois sem o estabelecimento de um ponto de conexão com o exercício da função pública não haverá a demonstração do indevido exercício de cargo, mandato, função, emprego ou atividade, nas entidades mencionadas no art. $1^{\circ}$, da Lei $n^{\circ}$ 8.429/92, consoante determinação expressa do art. $9^{\circ}$, da citada lei.

Sem a devida fundamentação, com a demonstração de graves e sérios indícios de que o agente público se utiliza de suas funções para auferir vantagens indevidas, verifica-se a ausência de um justo motivo para possibilitar a quebra do sigilo bancário/fiscal do investigado. O exercício indevido da função pública é o elo de plausibilidade para a solicitação da quebra de sigilo de dados do agente público investigado. Sendo ilegal partir-se tão somente dos saldos bancários para se construir um enriquecimento ilícito presumido, desacompanhado de uma atividade irregular do mesmo, além de não estar configurado o empobrecimento de outrem. Ou seja, parte-se de um enriquecimento sem se demonstrar que o ente público foi lesado ou empobrecido, além da inexistência de um ilícito funcional.

É nulo de pleno direito a quebra do sigilo fiscal e bancário, quando ausente a indispensável fundamentação, ${ }^{66}$ estabelecida a partir de fatos tidos, em tese, como ilícitos ou ilegais.

A quebra dos sigilos fiscal e bancário é medida excepcional, necessitando que haja indícios suficientes da prática de um delito, sendo insuficiente meras matérias jornalísticas,${ }^{67}$ tendo em conta que a acusação deverá ter plausibilidade e verossimilhança, sob pena de se produzir prova ilícita (art. 5 ${ }^{\circ}$, LVI, da CF).

Se é certo que não é absoluta a garantia dos sigilos bancário e fiscal, destaca-se que a respectiva relativização desta prerrogativa deve vir precedida de interesse público relevante e suspeita razoável de infração penal/administrativa, fazendo-se necessário a demonstração cabal de um nexo de causalidade entre o exercício da função pública e a movimentação A \& C R. de Dir. Administrativo e Constitucional, Belo Horizonte, ano 6, n. 24, p. 97-140, abr.jun. 2006 
bancária/fiscal produto de ilícito. Sendo insuficiente partir-se de saldos ou movimentações bancárias para se justificar a quebra do respectivo sigilo, visto que a motivação deve ser concreta e absoluta, longe de especulação ou de devassas indevidas e ilegais. A motivação deverá estar interligada a um ato ilícito consistente na prática do indevido exercício da função pública (art. 9 , Lei n ${ }^{\circ}$ 8.429/92): "Mandado de Segurança. Comissão Parlamentar Mista de Inquérito. Quebra de Sigilo Bancário, Fiscal e Telefônico. Falta de fundamentação. Nulidade do Ato Impugnado. Precedentes. 1. Se não fundamentado, nulo é o ato da Comissão Parlamentar de Inquérito que determina a quebra dos sigilos bancário, fiscal e telefônico. 2. Meras ilações e conjecturas, destituídas de qualquer evidencia material, não têm o condão de justificar a ruptura das garantias constitucionais preconizadas no artigo $5^{\circ}$, X e XII, da Constituição Federal. Segurança concedida." 68

Corroborando o que acabamos de afirmar, basta verificar que o $\mathrm{STF}^{69}$ vem repudiando devassa da intimidade de pessoas por meras conjecturas veiculadas em matéria jornalística: "Mandado de Segurança. Constitucional. Comissão Parlamentar de Inquérito. Roubo de Cargas. Quebra de Sigilos Bancário, Fiscal e Telefônico do Impetrante com base em Matérias Jornalísticas. Excepcionalidade da garantia constitucional da vida privada dos cidadãos se revela na existência de fato concreto. Ausência da causa provável justificadora das quebras de sigilo. Segurança Concedida.”

A falta de fundamentação é suficiente para invalidar as quebras dos sigilos bancário e fiscal, consoante remansosa jurisprudência do STF: "Privacidade. Sigilo de Dados. Regra e Exceção. A regra, constante

\footnotetext{
66 "Quebra de sigilo fiscal, bancário e telefônico, por Comissão Parlamentar de Inquérito. Nulidade do ato por falta da indispensável fundamentação" (STF. Rel. Min. Octávio Gallotti, MS n 23668/DF, Pleno, DJ de 24 nov. 2000. p. 88).

67 "Agravo Regimental em Petição. Contrato de Prestação de Serviços Advocatícios. Quebra de Sigilo Bancário, Fiscal e Telefônico. Matérias Jornalísticas. Duplicidade da Notícia-Crime. 1. O contrato de prestação de serviços advocatícios foi objeto de exame da decisão agravada. É equivocada a alegação do agravante de que a decisão agravada não apreciou a existência do contrato e seu conteúdo. Os honorários e a forma de pagamento contratados não podem ser apontados como ilegais, a ponto de permitirem que se instaure uma ação penal. O pagamento das parcelas avençadas no referido contrato, nada mais é do que uma obrigação da parte contratante. 2. Para autorizar-se a quebra dos sigilos bancário, fiscal e telefônico, medida excepcional, é necessário que hajam indícios suficientes da prática de um delito. A pretensão do agravante se ampara em meras matérias jornalísticas, não suficientes para caracterizar-se como indícios. O que ele pretende é a devassa da vida do Senhor Deputado Federal para fins políticos. É necessário que a acusação tenha plausibilidade e verossimilhança para ensejar a quebra dos sigilos bancários, fiscal e telefônico. 3. Declaração constante de matéria jornalística não pode ser acolhida como fundamento para a instauração de um procedimento criminal. 4. A matéria jornalística publicada foi encaminhada ao Ministério Público. A apresentação da mesma neste Tribunal tem a finalidade de causar repercussão na campanha eleitoral, o que não é admissível. Agravo provido e pedido não conhecido" (STF. Rel. Min. Nelson Jobim, Pet. n² 2805 AgR/DF, Pleno, DJ de 27 fev. 2004. p. 20).
} 
do rol constitucional de garantias do cidadão, é a manutenção de privacidade, cujo afastamento corre à conta da exceção. Decisão Judicial. Fundamentação. Sigilo de Dados. Afastamento. O princípio da vinculação resulta na necessidade imperiosa de os pronunciamentos judiciais serem fundamentados. Implicando o afastamento de garantia constitucional — intangibilidade de dados relativos à pessoa —, indispensável é a análise dos parâmetros do caso concreto, fundamentando o Estado-Juiz a decisão."70 "Mandado de Segurança. Comissão Parlamentar de Inquérito. Quebra de Sigilo Bancário e Fiscal. Falta de fundamentação. Legitimidade Ativa ad causam da ABAF. Desnecessidade de Procuração dos associados se há autorização expressa para representá-los. Precedentes. 1. As entidades associativas, quando expressamente autorizadas, têm legitimidade para representar judicial ou extrajudicialmente seus associados, sem necessidade de instrumento de mandato (CF, artigo $5^{\circ}$, XXI). 2. Os poderes de investigação próprios das autoridades judiciárias de

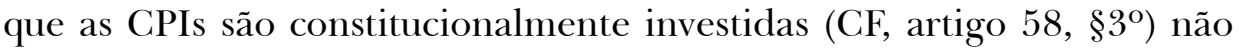
são absolutos. Imprescindível a fundamentação dos atos que ordenam a quebra dos sigilos bancários, fiscais e telefônicos, visto que, assim como os atos judiciais são nulos se não fundamentados, assim também os das comissões parlamentares de inquérito. Precedentes. 3. A legitimidade da medida excepcional deve apoiar-se em fato concreto e causa provável, e não em meras conjecturas e generalidades insuficientes para ensejar a ruptura da intimidade das pessoas (CF, artigo $\left.5^{\circ}, \mathrm{X}\right)$. Segurança concedida." 71

Como muito bem dito por Anna Maria Goffi Flaquer Scartezzini, ${ }^{72}$ os poderes previstos no texto da Lei Complementar no 105/01, "devem ser cautelosamente utilizados pela Administração, sob pena de ofensa injustificada ao contribuinte, a pretexto de instrução de processo administrativo. Como se trata de atividade sujeita ao exame da conveniência e da oportunidade desse procedimento junto às instituições financeiras, a atividade do Poder Judiciário se revela preponderante na fixação de limites para que se evite o abuso de direito ou de poder."

Até mesmo as Comissões Parlamentares de Inquérito, que possuem prerrogativas amplas e excepcionais, ("poderes de investigação próprios das autoridades judiciais”, CF, art. $58, \S 3^{\circ}$ ) para decretarem legitimamente a quebra dos sigilos de dados de pessoas ou empresas investigadas, devem

68 STF. Rel. Min. Maurício Corrêa, MS n 24.029/DF, Pleno, DJ de 22 mar. 2002. p. 32.

${ }^{69}$ STF. Rel. Min. Nelson Jobim, MS n 24.135/DF, Pleno, DJ de 6 jun. 2003. p. 32.

70 STF. Rel. Min. Marco Aurélio, HC n 86.094/Pe, $1^{\text {a }}$ T., DJ de 11 nov. 2005. p. 30

A \& C R. de Dir. Administrativo e Constitucional, Belo Horizonte, ano 6, n. 24, p. 97-140, abr./jun. 2006 
demonstrar, a partir de fortes indícios ou provas, a existência concreta de causa provável que legitime a medida sugerida, justificando a necessidade de sua ultimação no respectivo procedimento de ampla investigação dos fatos, sob pena de cometer abuso de poder.

Aliás, este posicionamento também está consagrado pelo STF através de sólidos julgados: STF. Rel. Min. Octávio Galloti, MS no 23.619/ DF, Pleno, DJ de 7 dez. 2000. p.7; STF. Rel. Min. Maurício Corrêa, MS $\mathrm{n}^{\mathrm{o}}$ 23.882/PR, DJ de 1 fev. 2002. p. 85; STF. Rel. Min. Celso de Mello, Ms no 23.868/DF, Pleno, DJ de 21 jun. 2002. p. 98; STF. Rel. Min. Maurício Corrêa, MS n ${ }^{\circ}$ 24.029/DF, Pleno, DJ de 22 mar. 2002. p. 32; STF. Rel. Min. Celso de Mello, MS no 23.964/DF, Pleno, DJ de 21 jun. 2002. p. 98.

Até mesmo na hipótese de execução da Fazenda Nacional, sem que se tenha esgotado todas as tentativas de obtenção dos dados do devedor pela via extrajudicial, não é cabível a quebra de sigilo fiscal ou bancário do executado; ${ }^{73}$ pois a proteção dos respectivos sigilos vigora como norma fundamental para toda a sociedade.

Desta forma, meras ilações e conjecturas não são suficientes para dar azo a quebra do sigilo de dados do agente público, quando necessária para investigação de ocorrência de qualquer ilícito, se dissociada de uma causa justa e coerente, através de uma fundamentação séria e robusta, visto que esta providência é uma excepcionalidade a regra, só cabível em casos de extrema relevância, onde a verossimilhança dos motivos embasadores do pleito se façam presentes.

Em assim sendo concluímos que o puro e simples pedido requerendo a quebra dos sigilos bancário e fiscal do agente público, sob argumento de que são necessários para a verificação de um possível enriquecimento ilícito presumido, deverá vir precedido do nexo de causalidade, consistente do exercício da função pública de maneira grave e ou ilícita pois, do contrário, prevalece a manutenção do direito fundamental do sigilo de dados do investigado.

Este é o justo e igualitário ditame da Constituição Federal para preservar a segurança jurídica de todos, objetivando que não haja perseguições de cunho político ou social por parte de quem detém o poder investigatório e sancionador.

\footnotetext{
71 STF. Rel. Min. Maurício Corrêa, MS n 23879/DF, Pleno, DJ de 16 nov. 2001. p. 8.

72 SCARTEZZINI, Anna Maria Goffi Flaquer. Princípios Constitucionais e a Atividade Administrativa Tributária nos Dias Atuais. In: VELLOSO, Carlos Mário da Silva; ROSAS, Roberto; AMARAL, Antônio Carlos Rodrigues do. [Org.]. Princípios Constitucionais Fundamentais: Estudos em Homenagem ao Prof. Ives Gandra da Silva Martins. São Paulo: Lex Editora, 2005. p. 143.
}

A \& C R. de Dir. Administrativo e Constitucional, Belo Horizonte, ano 6, n. 24, p. 97-140, abr.jun. 2006 
Transformar a investigação administrativa em um conjunto de arbitrariedades, com violações de preceitos constitucionais e infraconstitucionais, objetivando denegrir a imagem do homem público investigado é nocivo à sociedade e fere a dignidade e a moral do servidor público, merecendo severa reprimenda e repúdio por parte de todos, principalmente dos operadores do Direito, tendo em conta que os valores de segurança jurídica e de respeito aos direitos fundamentais são supremos e devem imperar num País cujo fundamento é o Estado Democrático de Direito.

\section{Conclusão}

Em assim sendo concluímos pela total falta de plausibilidade jurídica presumir-se enriquecimento ilícito do agente público, pelo simples movimento de sua conta bancária, ou pelo recolhimento da CMPF, visto ser necessário o nexo de causalidade, através de um ato omissivo ou comissivo praticado no exercício da função pública de forma ilícita e dolosa, não se admitindo a forma culposa.

A subsunção de uma conduta/ação na Lei de Improbidade Administrativa, por presunção ou suposição, além de ilegal, agride a todos os cultores do direito, porquanto o ordenamento jurídico não permite que haja leviana e irresponsável mácula na intimidade das pessoas. Há que se ter um mínimo de indícios da prática de um ato funcional ilícito, capaz de dar causa ao enriquecimento ilícito do agente público. Do contrário, a denúncia ou a acusação, é natimorta, e como tal merece todo o repúdio da sociedade.

Informação bibliográfica deste texto, conforme a NBR 6023:2002 da Associação Brasileira de Normas Técnicas (ABNT):

MATTOS, Mauro Roberto Gomes de. Ilegalidade de presumirem-se depósitos bancários como enriquecimento ilícito do agente público para fins de improbidade administrativa. A\&C Revista de Direito Administrativo e Constitucional, Belo Horizonte, ano 6, n. 24,

\footnotetext{
73 "Execução Fiscal. Quebra de Sigilo Bancário. Localização de Bens. Expedição de Ofício ao BACEN. 1. Não é cabível a quebra de sigilo fiscal ou bancário do executado para que a Fazenda Pública obtenha informações acerca da existência de bens do devedor inadimplente, excepcionando-se tal entendimento somente nas hipóteses de estarem esgotadas todas as tentativas de obtenção dos dados pela via extrajudicial. Precedentes. 2. A comprovação de que restaram esgotados todos os meios de localização de bens penhoráveis do executado exige apreciação de provas, vedada na via do recurso especial (Súmula 07/STJ). 3. Recurso especial a que se nega provimento" (STJ. Rel. Min. Teori Albino Zavascki, Resp. 733773/SP, $1^{\text {a }}$ t., DJ de 22 ago. 2005. p. 148). No mesmo sentido: Resp n 724178, Rel. Min. Teori Albino Zavaski, $1^{\text {a }}$ T., DJ de 22 ago. 2005. p. 144; AGRESP 747239/SP, Rel. Min. José Delgado, $1^{a}$ T., DJ de 8 ago. 2005. p. 298; RESP 306570/SP, Rel. Min. Eliana Calmon, 2a t., DJ de 18 fev. 2002; Ag.Reg. no AG 225.634/SP, Rel. Min. Fátima Nancy Andrighi, 2ª T., DJ de 20 mar. 2000.
} 
p. 97-140, abr./jun. 2006.

A \& C R. de Dir. Administrativo e Constitucional, Belo Horizonte, ano 6, n. 24, p. 97-140, abr.jun. 2006 